\title{
مظاهر الدلالة الصوتيّة لأسماء الأفعال في القران الكريم
}

\section{Aspects of the phonetic significance of the names of verbs in the Holy Qur'an}

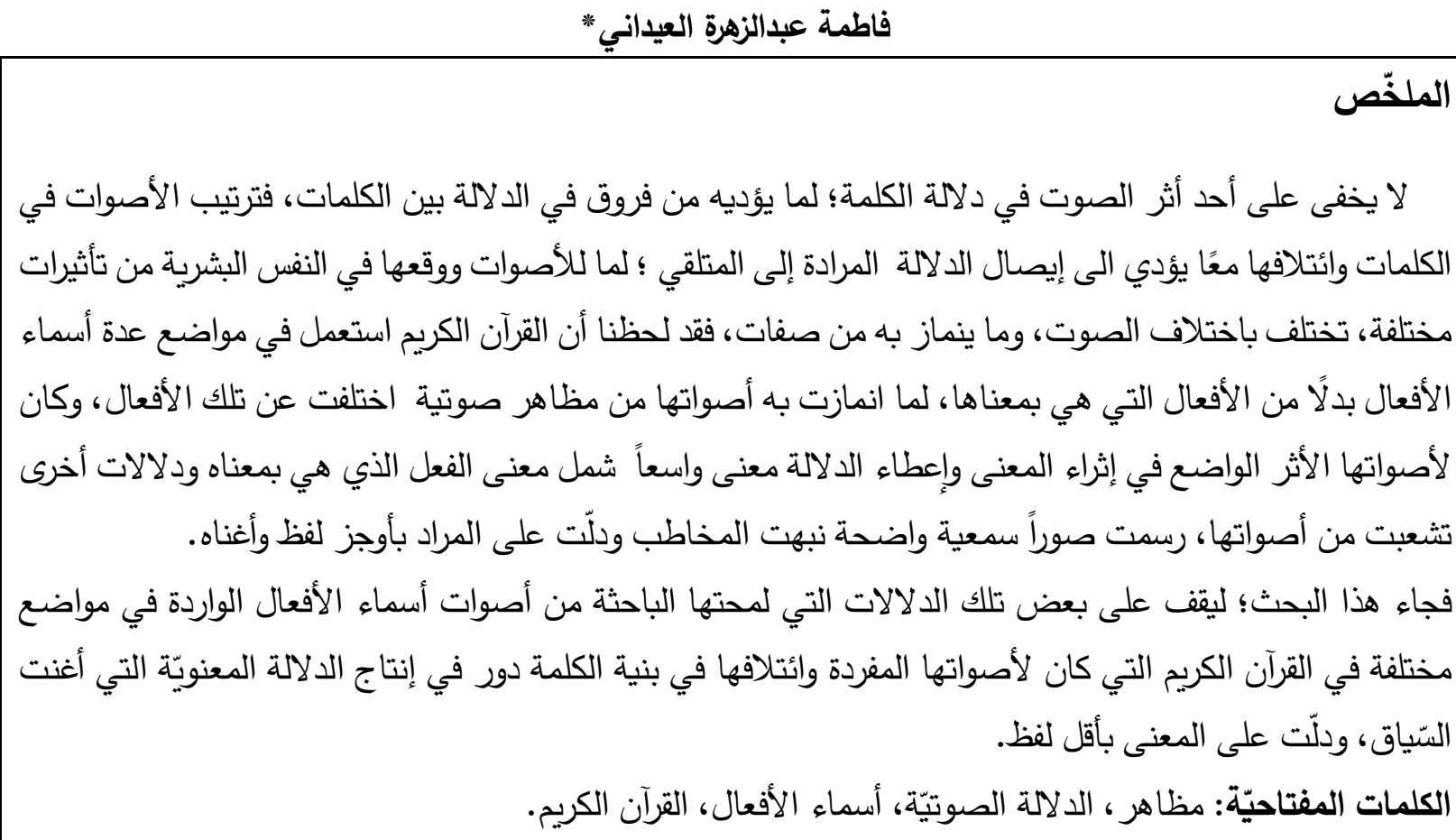

\section{Abstract}

No one can deny the effect of sound in the meaning of the word, owing to the differences it shows among the words, the order of the sounds in the words and their coalition together lead to the delivery of the desired significance to the recipient due to the sounds' various effects, echos and resonances in the human's self, which vary according to the variable of sound alongside with its distinctive characteristics. We noticed that the Holy Qur'an used in several places the names of the verbs instead of the verbs that are in their meaning, because their sounds were distinguished by the phonetic manifestations that differed from those verbs, and their sounds had the clear effect in enriching the meaning and giving the connotation a broad meaning that included the meaning of the verb whose meaning and other connotations branched off, which- in turn, drew vibrant audio images that alerted the addressee and indicated what was meant by the shortest and richest pronunciation possible.

The present research is an attempt to investigate those meanings that the researcher noticed from the sounds of the names of the verbs mentioned in different places in the Holy Qur'an, whose individual sounds and their combination with the structure of the word has a role in producing the semantic significance that enriched the context, and indicated the meaning with the briefest wording.

Key Words: The Holy Quran, Aspects of the Phonetic Significance, Names of Verbs 


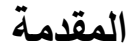

وضعت اللغة للتعبير (أو الدلالة) عما في نفس متكلميها، وكل الجوانب الأخرى هدفها تبيين المعنى، والصوت جزء من بنية الكلمة، واختلاف صوت واحد في كلمتين متشابهتين يؤثر في اختلاف المعنى.(1) وأن علاقة الإنسان بالأصوات علاقة حميمة، فهي لصيقة بوجوده وطبيعته؛ لانّ النظام الصوتي نظام ملكوتي مرتبط بالحقيقة الإلهية، حتى عدت اللغة ظاهرة اجتماعية(2)، ووسيلة التواصل والتفاهم بين البشر، فهي بالإضافة إلى ذلك ظاهرة صوتية، فقد عرفها ابن جني بقوله: "أصوات يعبر بها كل قوم عن أغراضهم"(3) ، فالتعريف السابق يدل على أن اللغة تتضمن جوانب ثلاثة، الجانب الصوتي، والجانب الاجتماعي إضافة إلى الجانب الوظيفي(4)، فاللغة لها ما يميزها عن سائر الرموز الأخرى غير اللغوية.

ودراسة أي نصّ أدبي تستوجب البدء بالأصوات بوصفها وحدات مميزة، تتتج منها آلاف الكلمات ذات الدلالات المختلفة، "وقد يفرقون بين المعنيين المتقاربين بتغيير الكلمة حتى يكون تقارب مابين اللفظين كتقارب ما بين المعنيين، كقولهم للماء المالح الذي لا يشرب إلا عند الضرورة: شريب، ولما كان دونه مما يتجوز به: شربب"(5)، وبما أن القرآن أرفع نص على الإطلاق، من حيث البناء والغاية والدلالة، فقد وظّف كل ما تمتلكه الأصوات اللغوية من ميزات في اختيار ألفاظه، وترتيب الأصوات فيها، فغدا الصوت فيه صورة متميزة للتناسق الفني، وتحقيق دلالاته المرجوة لما ينماز باه من صفات مختلفة باختلاف أنواعه، فكان أداته في إيصال معانيه المتفردة والإحاطة بها، بحيث لا يمكن أن تحلّ لفظة مكان أخرى من حيث تتاسق أصواتها وائتلافها مع سياقها العام الذي يؤدي الغرض المراد منه، فإن: "الحرف الواحد من القرآن معجزٌ في موضعع، فإن يمسك الكلمة التي هو فيها ليمكك بها الآية والآيات الكثيرة، وهذا هو السّر في أعجازه الأبدي، فهو أمر فوق الطبيعة الإنسانية، وفوق ما يتسبب إليه الإنسان، إذ هو الخلق الحيّ تمام المشابهة، وما أنزله إلا الذي يعلم :(البِّرَّ في السموات والأرض)"(6). لذا جاء هذا البحث ليجلي اللثام عن استعمال القران الكريم لأسماء الأفعال في بعض آياته، متخذاً مما انمازت به تلك أصوات من صفات، لبيان ما تدل عليه من دلالات أدت المعنى المطلوب بأوجز لفظ. قال الخطابي (ت: 383-388هـ): إن الكلام إنما يقوم بأشياء ثلاثة: "لفظ حاصل، ومعنى به قائم، ورباط لهما ناظم، وإذا تأملت القرآن وجدت هذه الأمور منه في غاية الشرف والفضيلة، حتى لا نرى شيئاً من الألفاظ أفصح، ولا أجزل، ولا أعذب من ألفاظه"(7)، وكان من فضيلة القران أنه استوعب جميع مظاهر الدلالة في مجالاتها الواسعة، فالخطاب فيه يبتغي الإقناع

(1) التحليل اللغوي في ضوء علم الدلالة، محمود عكاشة، دار النشر للجامعات، القاهرة، 2011: 9

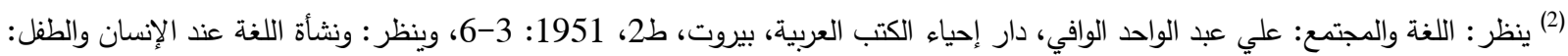

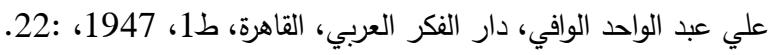

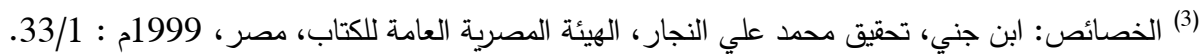

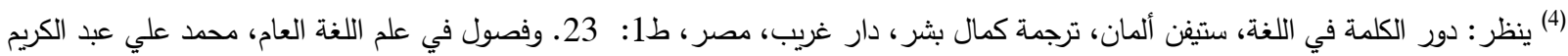

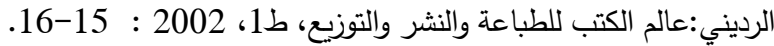

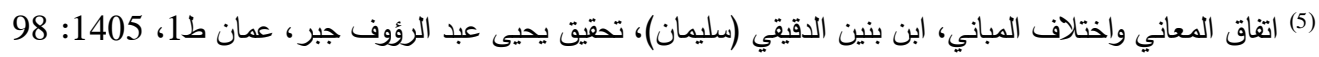

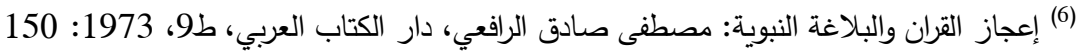

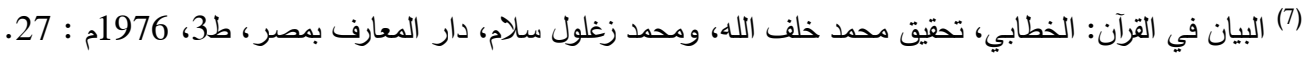


ويهدف إلى صياغة واقع جديد، وغرضه الإصلاح والإرشاد فاستعمل ألفاظًا، أحاطت بالمعنى المراد تبليغه. وقبل البدء في بيان تلك الدلالات لا بدّ من تعريف أسماء الأفعال بصورة عامة من دون الخوض بالتفاصيل، وتثعب الآراء؛ لانّ الدراسة دلالية

\section{أهمية البحث:}

تأتي أهمية البحث من أهمية الدلالة الصوتية للأسماء الأفعال ومواضع استعمالها في القرآن، لذا يمكن أن يسهم هذا البحث في إثراء معلومات الدارس فيما يتعلق بالأصوات ودورها في دلالة أسماء الأفعال، وسبب استعمالها في مواضع عديدة من القران الكريم.

\section{هدف البحث}

يهدف البحث إلى بيان أهمية استعمال أسماء الأفعال بدلًا من الأفعال التي هي بمعناها في مواضع مختلفة في القران الكريم؛ لما تمتلكه من خصائص صوتية كان لها الدور الأبرز في الدلالة على معاني مكثقة، وذات طابع دلالي يتسم بثمولية الدلالة، وتوضيحها من الناحية الزمنية والصوتية، بأبلغ لفظ وأوجزه.

\section{الاراسات السابقة}

تناول العديد من الدارسين أسماء الأفعال في دراساتهم وبحوثهم، أذكر ما اطلعت عليه منها:

1. أسماء الأفعال وأسماء الأصوات في اللغة العربية، محمد عبد الله جبر، دار المعارف، مصر، 1980. ففي هذا الكتاب لم يتجاوز المؤلف ما كُتب في الكتب النحوية عن أسماء الأفعال بأنواعها وعملها ودلالاتها، وأحكامها الإعرابية،

ودراستي صوتيّة تختلف عنها.

2. معجم أسماء الأفعال في اللغة العربية، أيمن عبد الرزاق الثوا مطبوعات مجمع اللغة العربية بدمشق، وهو معجم شامل لأسماء الأفعال، ولم يتطرق للدلالة الصوتيّة.

3. (أسماء الأفعال بين النظرية والاستعمال)، مريم حسن حسن إبراهيم (رسالة ماجستير)، الجامعة الأردنية، كانون الثاني،2003- فقد تناولت الباحثة أسماء الأفعال وفقاً لما استقرت عليه كتب النحو، ووفقاً لاستعمالها الجاري في عينة من النصوص تمثل مختلف العصور العربية ابتداء بعصور الاحتجاج وما تلاها، وانتهاء بالعصر الحديث، وهي دراسة

$$
\text { وصفية إحصائية لا تمت لدراستي بصلة. }
$$

4. بحث (أسماء الأفعال في الاستعمال القرآني)، زهير محمد، مجلة الأقصى للعلوم الإنسانية، مج 22، العدد2، وقد

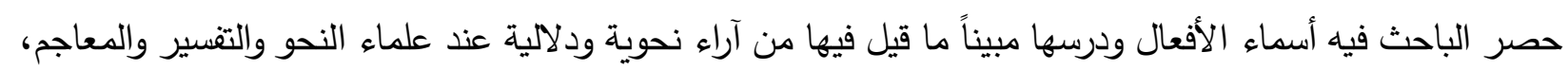
وقد أفدت منه في دراستي، إلا أن دراستي تختلف عنها كونها ركزت على الدلالة الصوتيّة للصوت المفرد في اسم الفعل وائتلافه مع غير من أصوات الاسم في إيصال الدلالة. أسماء الأفعال: 
هي ألفاظ تؤدي معاني الأفعال، ولكنها لا تقبل علامتها، ولا تأتى على صيغها، والذي حمل النحاة على قول ذلك، "والذي حملهم على أن قالوا إن هذه الكلمات وأمثالها ليست بأفعال، مع تأديتها معاني الأفعال، أمر لفظي وهو أن صيغها مخالفة لصيغ الأفعال، وأنها لا تتصرف تصرفها...)(8)، فالأمر لفظي في عدها أسماء أفعال وليست أفعالًا حقيقية، ومنهم من عدّ بعضًا منها أسماء أصوات ك( صه،، وأف، ومهه..)، أي أنها اسم للصوت الذي تمثله، ولو رجعنا إلى كتب النحو نجد أنها عرّفت أسماء الأصوات بأنها: "كل لفظ حُكي به صوت، أو صُوّت به للبهائُ، ولما يعقل عموما فالأول نحو (قب) حكاية وقع السيف، و(طق) لوقع الحجارة، والثاني ك (عدس) لزجر البغل، وهيد لزجر الإبل"(9)، وذكر الرضي من أسماء الأصوات قسمًا ثالثاً، وهي الأصوات الخارجة عن فم الإنسان: "غير موضوعة

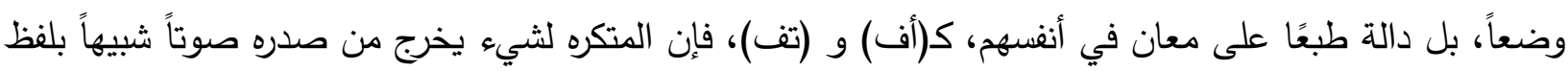
(أف)، ومن يبزق على شيء مستكره يصدر منه صوت شبيه ب(تف). وكذلك (آه) للمتوجع، أو المتعجب، فهذه وشبهها أصوات صادرة منهم طبعاً، ك(أح) لذي السعال، إلا أنهم لما ضمنوها كلامهم لاحتياجهم إليها، ونسقوها نسق كلامهم وحركوها تحريكه، وجعلوها لغات مختلفة"·(10)

وما جعل النحاة يختلفون فيها وفي ماهيتها هو أمر لفظي، راجع بالأساس للصيخ والأصوات، وهذا ما نراه في استعمالها في القران الكريم، فقد استعملت في سياق يتطلب أصواتا غير موجودة في دلالتها الفعلية المتضمنة فيها، بمعنى أن صيغ الأفعال التي هي بمعناها لم تؤدِ الدلالة المطلوبة منها صوتًا ودلالة وحدثًا؛ لذا آثر القران الكريم استعمال صيخ أسماء الأفعال في مواضع استوجبت دلالات تقوق دلالات الأحداث من حيث الزمن، وبذا جمع القرآن في استعمالها صوت الفعل ودلالته، وكثف فيها معاني أخرى منبثقة من أصواتها، فأوجز واختصر ، ودلّ وأوسع، والله أعلم. ومن تلك الدلالات:

\section{أولًا: دلالة الإسراع}

وهذه الدلالة الصوتية نجدها في أصوات اسم الفعل (هات) في سياق التحدي والإسراع في طلب تقديم الدليل، وقد ورد اسم الفعل (هات) في أربع آيات من القران الكريم، وهي: في قوله تعالى: "وَقَالُواُ لَن يَذْخُلَ الْجَنَّةَ إِلاَّ مَن كَانَ هُودًا

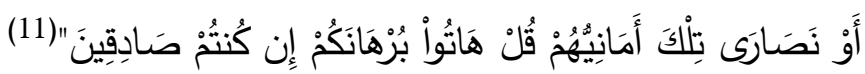

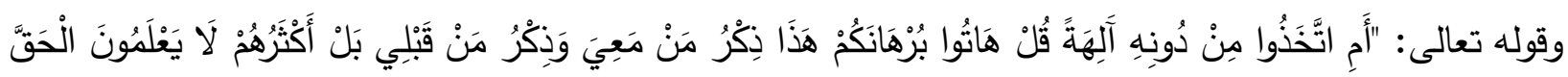

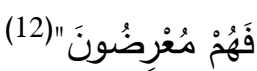

(83 شرح الرضي على الكافية، رضي الدين الاستراباذي ، تحقيق وتصحيح وتعليق، يوسف حسن عمر، منشورات جامعة قابوس بنغازي، 1975م: 2 / 


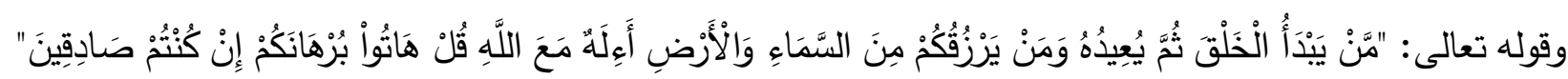

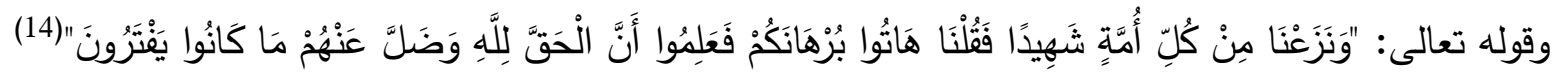
نلاحظ من الآيات السابقة، هناك سرعة في طلب تقديم الدليل والبرهان، فتطلب ذلك أمراً فيه صدى في النفس،

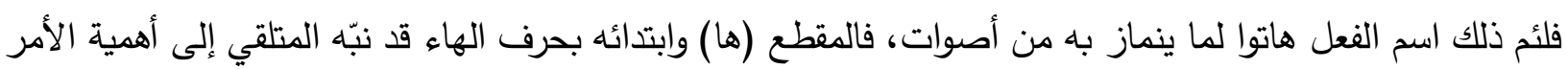

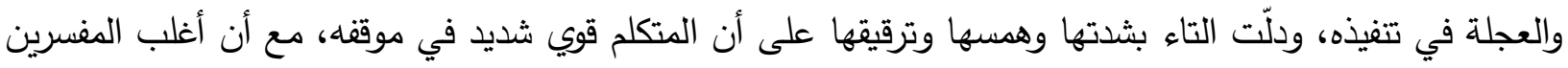

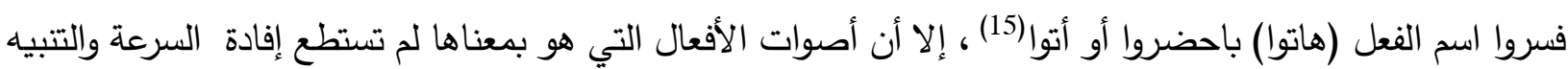

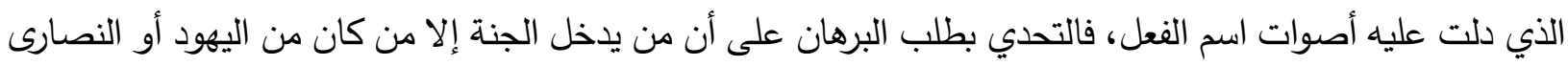

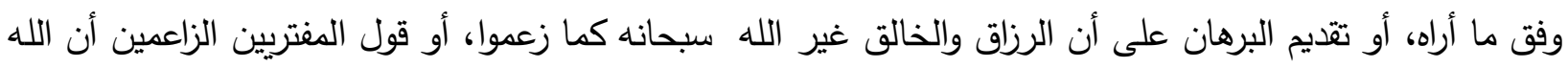
حرّم عليهم ما هم مُحرّموه من حروثهم وأنعامهم، كلها ادعاءات، فطلب البرهان على إثبات قولهم مستحيل، فجاء الطلب

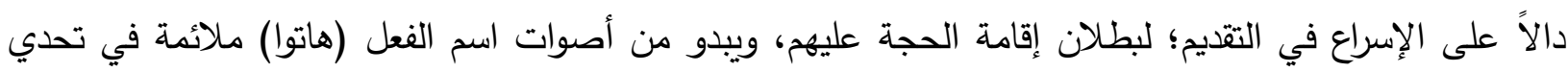
الخصم والإسراع في تبكيته بدليل أن القران الكريم عندما أراد تحديهم على الإتيان بمثله، أو سورة من من مثله التهات استعمل

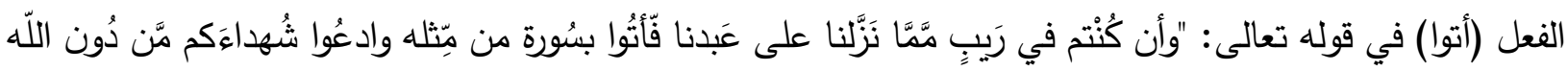
إن كُنتُ صادقين" (16) - (16)

وهنا يبدو من أصوات الفعل (فأتوا) أن طلب التقديم والإتيان ليس بسرعة اسم الفعل هاتوا، فطلب التحدي للإتيان

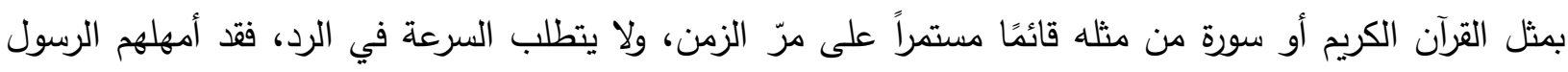
للإتيان بمثله، فلما أعجزهم ذلك، تحداهم بإتيان ولو بسورة واحدة من مثله، فالتحدي مستمر وقائم إلى ما شاء الله تعالى، وهذا دليل على إعجاز القران في اختيار ألفاظه بما يتلاءم مع السياق وتحقيق المراد.

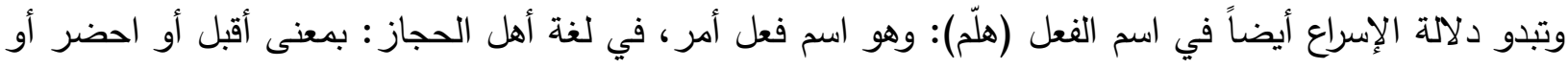

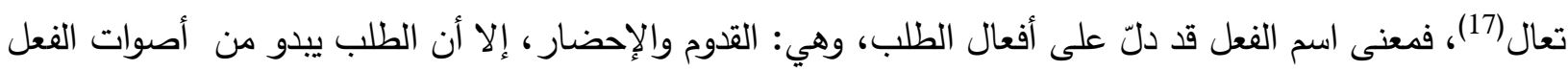

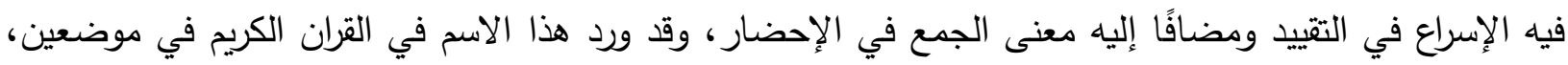

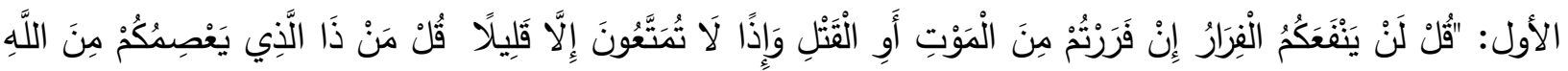

(15) ينظر : تفسير الطبري من كتابه جامع البيان في تأويل آي القرآن، الطبري، هذبه وحققه وضبط نصه وعلق عليه: بشار عواد معروف، عصام 


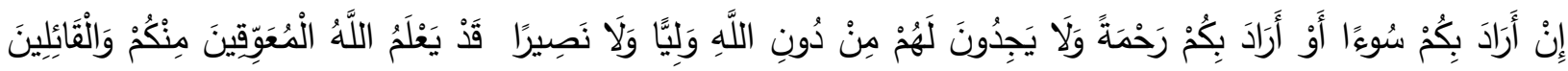

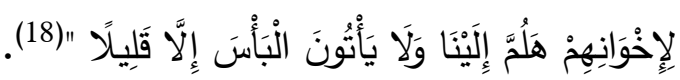

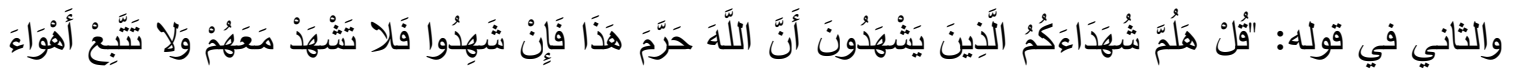

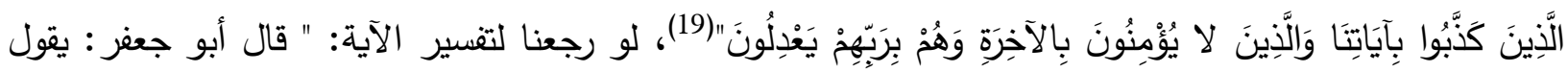

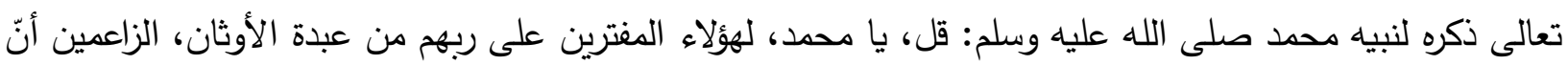

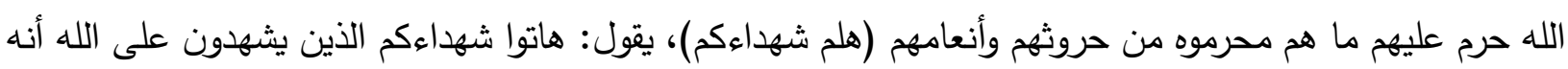

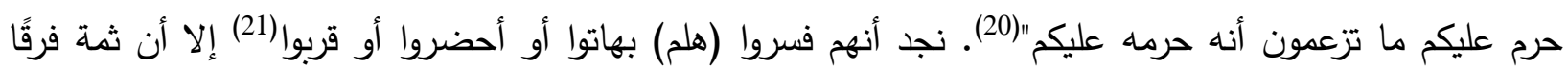

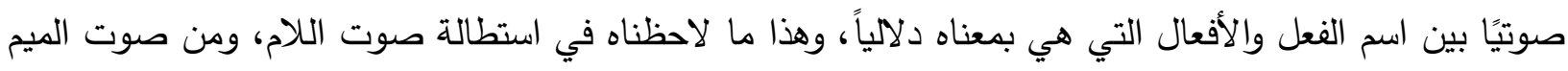

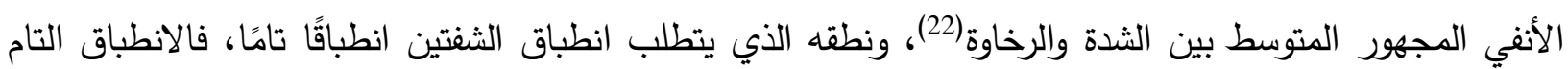
للشفتين دلّ على طلب الإحضار المتجمع لأولئك الدعيين والزاعمين.

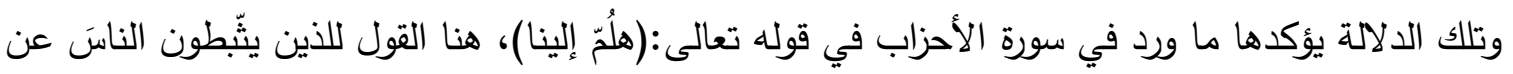

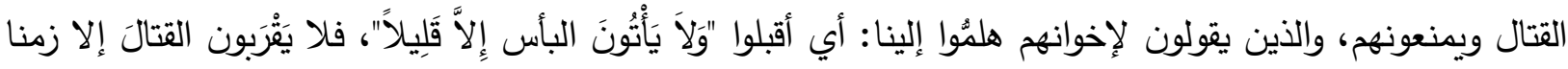

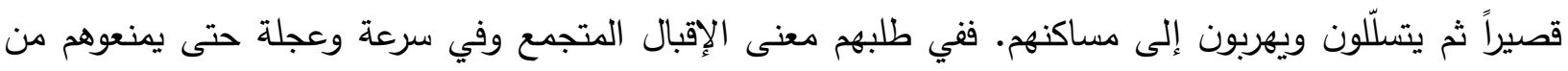

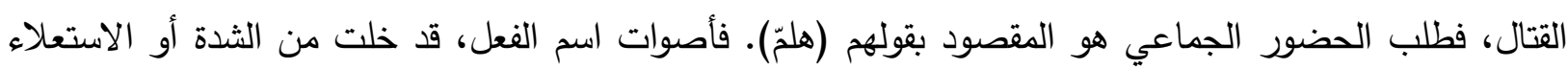

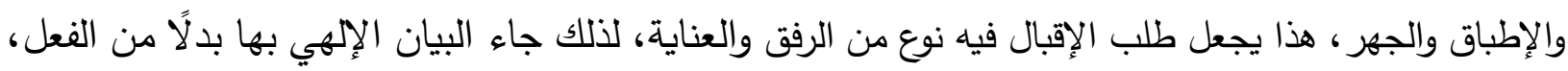
وهو من منطلبات الدعوة الإسلامية من الرفق والصبر على عناد المشركين.

وكذلك وجدنا معنى الإسراع واضحًا في اسم الفعل (هيت لك)، في قوله تعالى في سورة يوسف على

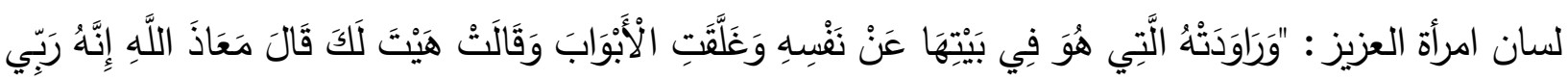

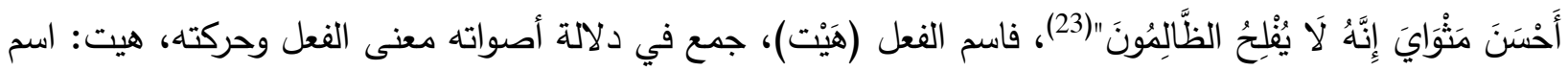

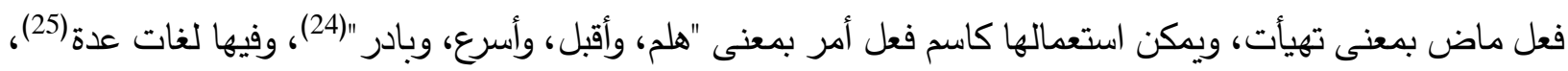

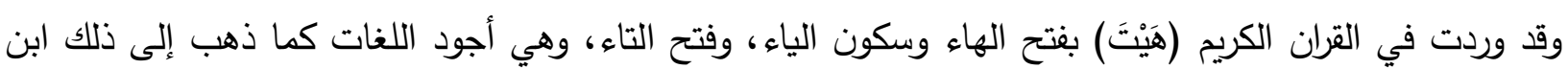

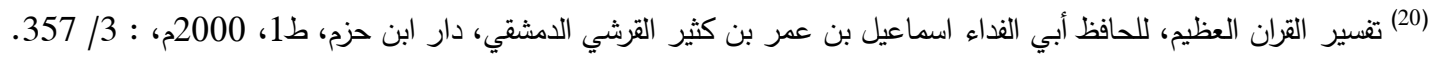

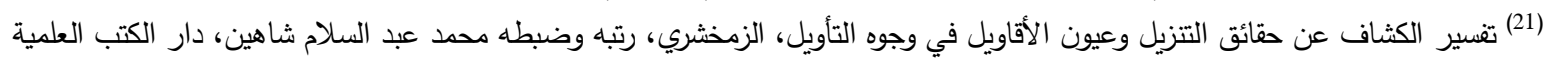

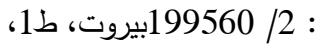

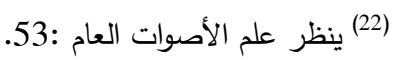
23 (23) يوسف : 23

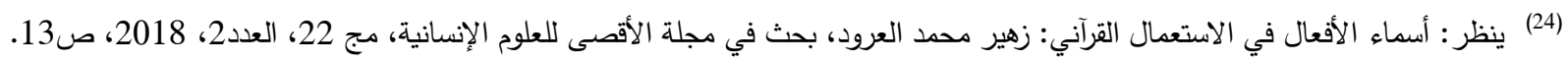

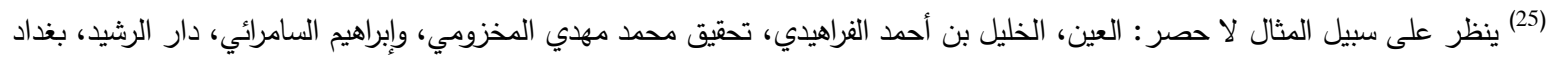

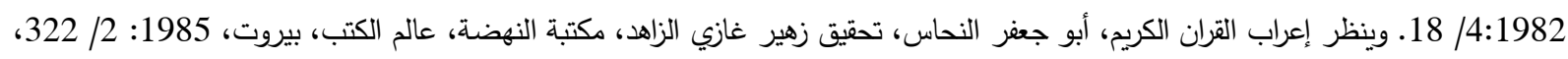

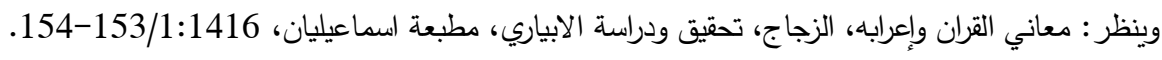


جني (26)، فأصوات اسم الفعل (هَيْتَ) رسمت بأصواتها وحركاتها ما كانت عليه امرأة العزيز من الاضطراب والعجلة، فصوت الهاء المهوس وعمق مخرجه، ولولا وجود الحفيف عند نطقها لما سمع عند نطقها غير الزفير العادي(27)، قد صوّر ما هي عليه من حرص على عدم ملاحظتها من زوجها أو أحد من حاشيتها، وصوّرت الياء وهي من أصوات المد، طول فترة تهيؤ امرأة العزيز وتزينها، وقد حركت الياء بالسكون لدلالة على الهدوء والحرص والترقب منها، ليأتي صوت التاء الانفجاري المهموس الذي يتصف بدلالته على الاضطراب(28)، لكثف حال امرأة العزيز وهي مضطربة، خائفة، لذا كان طلب الفعل الصادر منها على وجه السرعة بقولها (هيت لك)، فقد جمع (اسم الفعل) في دلالته اللغوية والصوتية بين الدلالة على حالتها، وغرضها وهو طلب الإقبال والمبادرة إليها على وجه السرعة، فهي مضطربة متهيئة وبكامل زينتها؛ من أجل إتمام ما ترجوه على عجلٍ وترقب، فأي فعل هو بمعناه لا يحمل تلك الدلالات التي حملها اسم الفعل (هَيَتَ)، فقد أوجز وعبّر عن ما تريده، وعن حالتها المضطربة؛ لأن الألفاظ " ليست سواء في دلالتها على المعنى، فمن الكلمات ما هو أصدق من الكلمات الأخرى، وألصق بالمعنى، وأكثر تمثيلًا له أمام العيون"(29)، وهذا لهاء يفسر وروده مرة واحدة في القرآن الكريم، لا سيّما في هذا الموقف، فكان لفظ اسم الفعل (هيت) وما تحمله أصواته من دلالات وإن اختلفت اللغات في التلفظ به، يحمل دلالة التهيؤ والطلب المشوب بالاضطراب، طلب إقبال النبي يوسف بأسرع وقت، مع مبالغتها في التزيين لاستدراجه بأسرع وقت مع ذلك لم تفلح. كما نلمح من استعماله في موضعه دهاء ومكر زوجة العزيز ، وعفة وطاهرة نبي الله، فمع تلك المغريات لم يستجب لها، فقد تجلت الحكمة في نظم كتاب الله، ففي كل لفظ نجد آية تدّل على إعجازه.

\section{ثانيًا: دلالة الاكتفاء المطلق}

وهذا ما نجده في دلالة أصوات الفعل (حسب)، وفيه خلاف من كونه فعلاً ماضياً: أي كفاهم، أو اسم فعل أمر بمعنى:

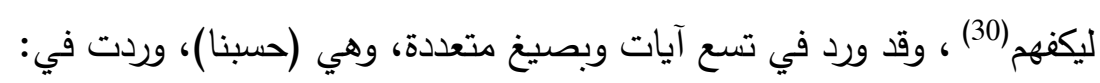

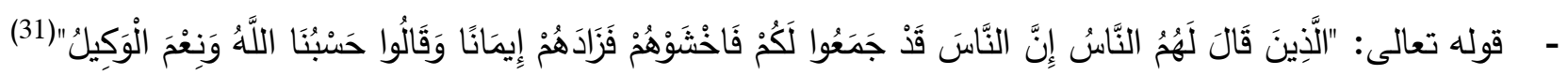

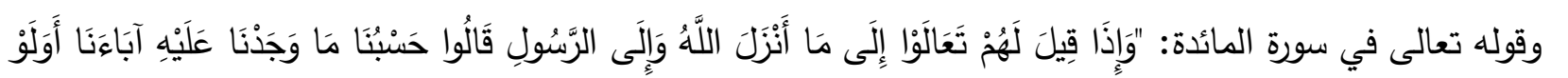

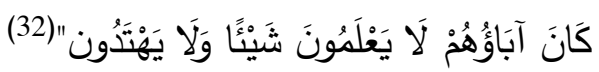

(26) ينظر: المحتسب في تبيين وجوه القراءات والإيضاح عنها أبو الفتح عثمان (ابن جني) تحقيق علي النجدي ناصف وآخرين، مصر،

2004 .337/1:

:

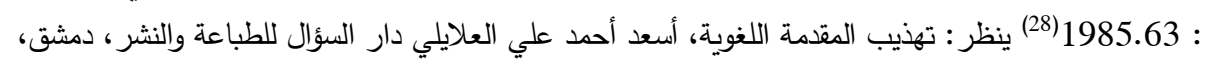

: 244. نقلا عن الخطابة لأرسطو.1977 (29) النقد الأدبي الحديث: محمد غنيمي هلال، دار نهضة مصر للطباعة والنشر والتوزيع، : 1994(30) ينظر: الدر المصون في علوم الكتاب المكنون، السمين الحلبي، تحقيق الثيخ علي معوض وآخرين، دار الكتب العلمية، بيروت، لبنان 


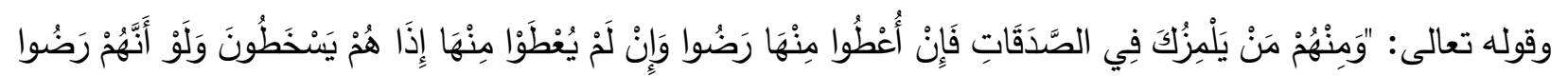

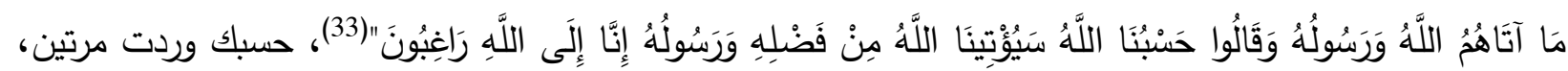

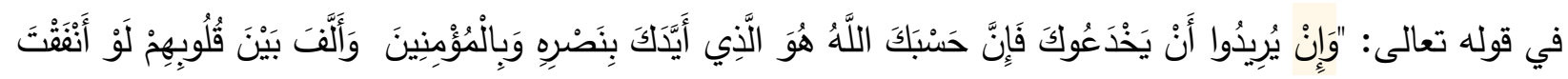

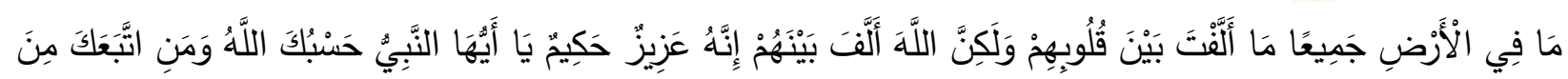

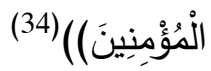

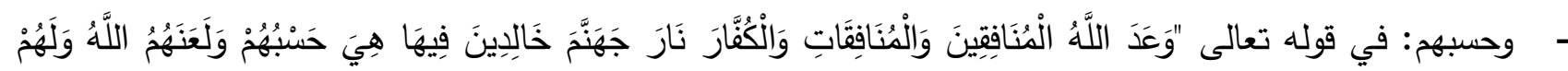
عَذَابُ مُقِيمِ" (35)

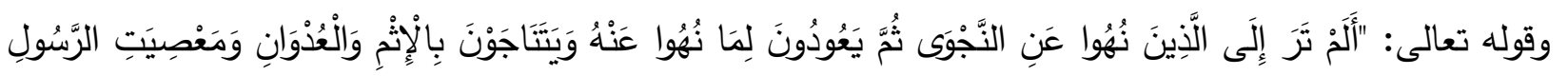

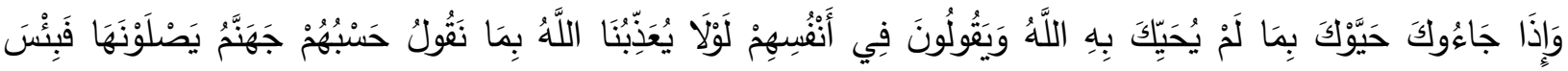
الَْصَيرُ "(36)

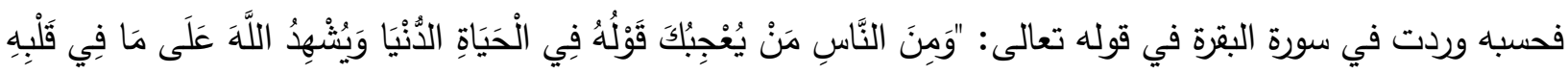

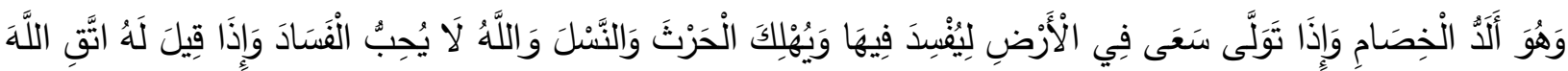

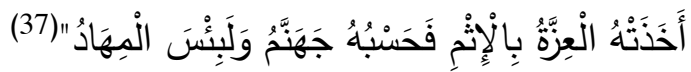

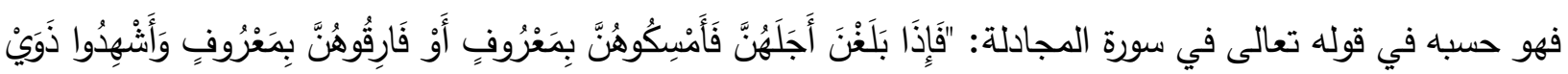

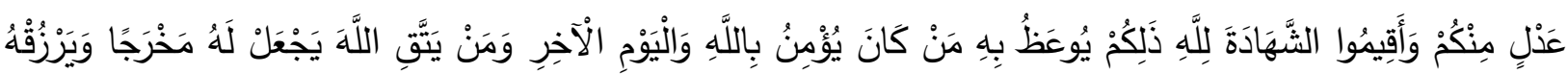

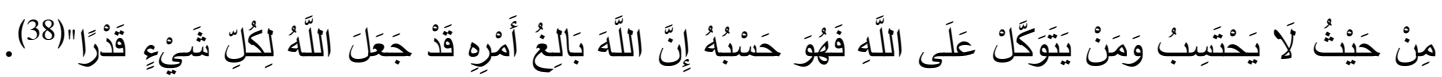

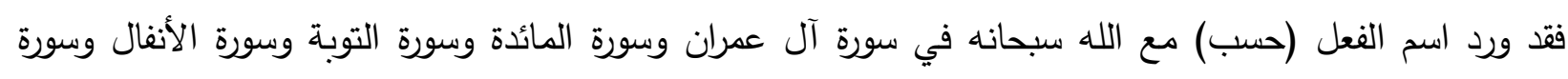
المجادلة (حسبنا الله، حسبنا الله، حسبك الله، حسبك الله، فهو حسبه)، فالتحسب والاكتفاء المطلق مع الله سبحانه،

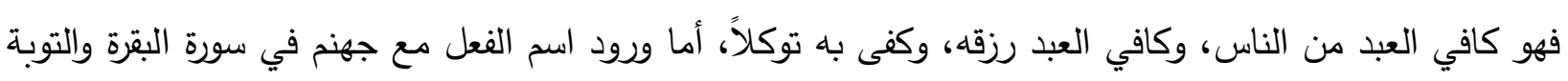
والمجادلة (فحسبه جهنم ولبئس المهاد، نار جهنم خالدين فيها هي حسبهم، حسبهم جهنم يصلونها فبئس المصير). فلو تأملنا ما سبق من الآيات، وفي استعمال القرآن اسم الفعل (حسب)، للّّ الفعل الذي هو بمعناه من دلالة

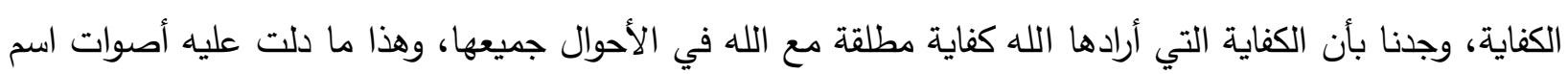

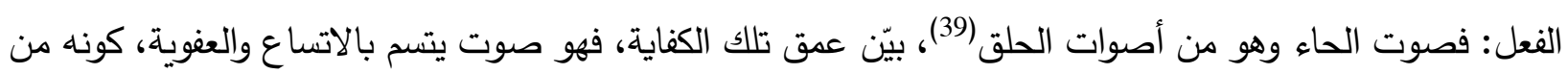

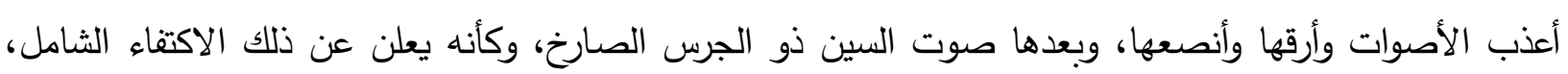

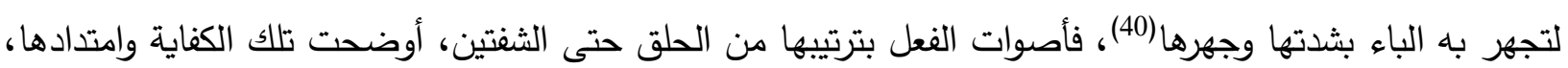


وكأنّ المكتفي أو المتحسب قد بُح صوته مع بحة الحاء وخروج الهواء عند نطقها، ليعلن أن الاكتفاء يكون بالله وحدة عند المحتسب.

كما خاطب الله جل شأنه نبيه صلى الله عليه وسلم في سورة الأنفال، فقد وردت مرتين فيها إذا جعل كفاية الرسول وحسبه هو الله وحده، وفي الآية أخرى بأن حسبك وكفايتك الله والمؤمنون؛ أي "يا أَيْهَا النَّبِّيٌ المخبر عن الله

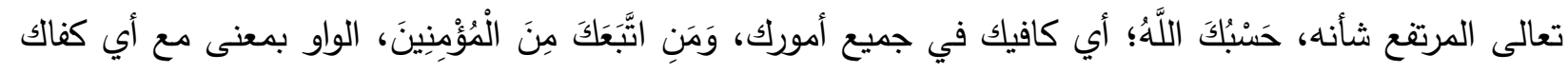
وكفى اتباعك ناصرًا، كقولك حسبك وزيدًا درهم، أو عطف على اسم الله تعالى؛ أي كفالك الله والمؤمنون، والكافي الحقيقي هو الله تعالى، وإسناد الكفاية إلى المؤمنين لكونهم أسبابا ظاهرة لكفاية الله تعالى" (41). فالكفاية مطلقة مع الله عزوجل، فهو كافي رسوله.

ودلالة الكفاية للكافرين مع جهنم كفاية نلمح منها التبكيت وإذلال المنافقين والكفار، فجهنم هي حسبهم وكفايتهم الشاملة، فأي كفاية مطلقة شاملة لهم في جهنم، فهي جزاؤهم الكافي لهم لكفرهم ونفاقهم، فأصوات اسم الفعل أبلخ في دلالة الكفاية فضلًَ عن أحاطتها بدلالات أخرى مشعة من طريقة لفظها مع السّياق الذي ترد فيه. ففي التوكل على الله هي الثاملة والمطلقة، وما دونها كفاية، ولا بعدها، وهذا واضح في سورة الطلاق "ومن يتوكل على الله فهو حَسُبُهُ".

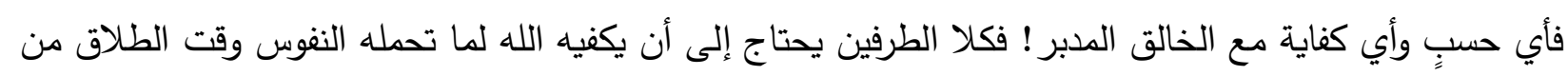
التشاحن والغضب فهو كافي الطرفين، وإن فكر أحدهما أن يغبن الآخر، فأي عظمة شاملة كافية تجلّت في كفايته سبحانه، فقد أعطت أصوات (اسم فعل) إيحاءً، شعوريًا، وخرجت عن كونها أصواتاً محضة إلى دلالات حركّت المعنى وأرشدت إلى قصديته.

\section{ثالثاً: دلالة الأمر الصارم:}

وهذا ما نجده في اسم الفعل المنقول عن الجار والمجرور (عليك)، واسم الفعل المنقول عن الظرف (مكانك)، واسم الفعل (وراءكم)، فاسم الفعل (عليك) بمعنى ألزم وقد ورد (42) في قوله تعالى في سورة المائدة: "يأيها الََّّينَ آَتنُوا

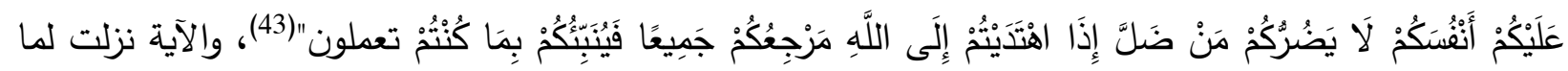
كان المؤمنون يتحسرون على الكفرة ويتمنون إيمانهم، وفيهح من الضـل بحيث لا يكادون يروعون عنه بالأمر والنهى هي

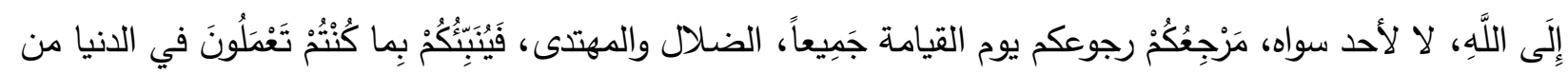

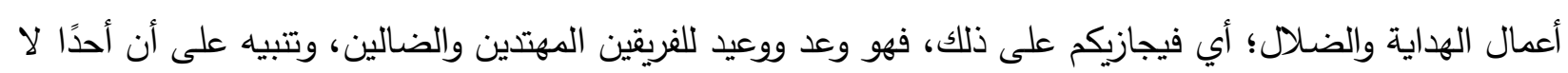
يؤاخذ بعمل غيره، ولا يتوهمنّ أن في الآية رخصة في ترك الأمر بالمعروف والنهى عن المنكر مع استطاعتهما، كيف لا، ومن جملة الاهتداء أن ينكر على المنكر حسب الطاقة".(44)

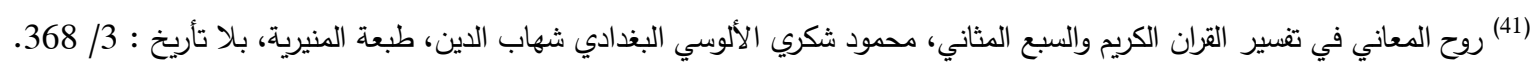

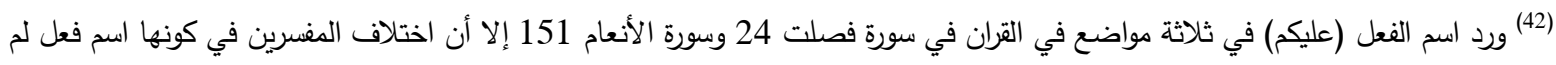




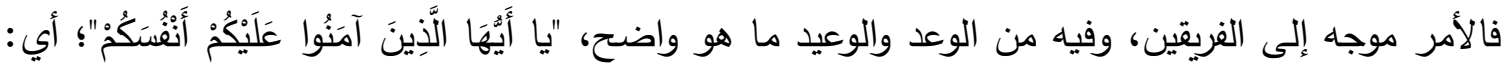

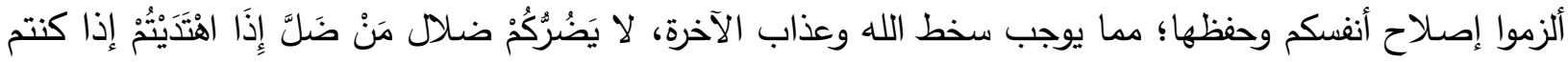
مهتدين. فأصوات اسم الفعل المنقول من الجار والمجرور (عليكم) دلت على الأمر الصارم الموجه، فدلالة صوت العين في مقدمة حرف الجر (على) إضافة إلى دلالة صوت العين، دلالة حرف الجر ( على) على الاستعلاء وصوت العين من أصوات الحلق التي عدها الخليل بن أحمد الفراهيدي من أطلق الحروف وأضخمها جرساً(45)، قد بيّت صرامة الأمر الموجه ولزوم تتفيذه، بمعنى ألزموا أنفسكم وأحيطوا بها واستعلوا عليها في كبتهم عن ما تقوم به، وهذه المعاني نجدها في صوت العين، في تناسقه مع أصوات اسم الفعل الأخرى، كاللام في استطالتها وجهرها، والكاف وهو صوت يسمع له صوت انفجاري، فعند خروج الهواء بعد انفصال الحنك الأعلى عن الجدار الخلفي عند انفصالهما انفصالا مفاجئًا يحاكي وجوب انفصال المؤمنين عن أهل الضلال وبثدة، فحاكت أصوات اسم الفعل الأمر الموجه بصارمة إلى الفريقين معًا، ووجوب الالتزام به، فهو أمر واضح وبيّن لا رجعة فيه. وحين نقارن بين دلالات الأصوات في اسم الفعل (عليكم)، وبين دلالة الفعل الذي بمعناه (ألزم) ندرك حقيقة اختياره ووضعه في السياق. أما في اسم الفعل (مكانك) وهو من الأسماء المنقولة من ظروف المكان: وهو اسم فعل أمر بمعنى اثبت(46) ورد في

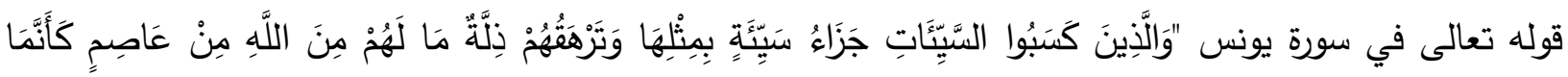

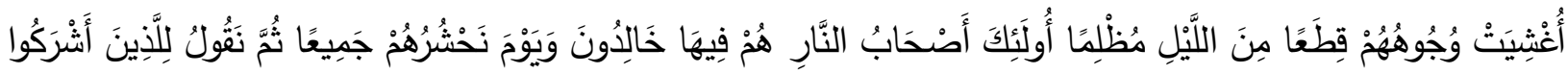

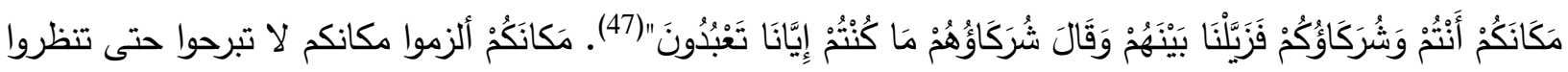
ما يفعل بكم. فدلالة الأمر الصارم واضحة من أصوات الفعل الذي دل في معناه على الإلزام بالأمر تتفيذًا وبقاء في المكان، فحمل الدلالة الإلزامية المكانية، فتكرار صوت الكاف في اسم الفعل، وهو صوت طبقي شديد(48)، الذي يتطلب نطقه جها ومشقة، قد حاكى عظم الأمر وشدته، ووجوب الثبات، لأن معنى الثبوت هو الاستقرار، وثبت على موقفه: يدوم عليه ولا يغيره، والثبات ضد الزوال، لذا يُقال ثبت يَثُبتُ ثباتاً (49) ، وهذا ما أراده الله عز وجله ونل من الثبوت والاستقرار المكاني، في أمر صارم موجه يتعالى مع انفجارية صوت الكاف. فدلالة أصوات اسم الفعل (مكانكم)، الكاف بثدتها والنون وكونه أول حروف اسم الفعل وآخره، وهي صوت شفوي أنفي تتطبق الثفتان انطباقا تاما عند نطق(50) ، صوّر عظم الأمر عند انطباق الثفتين مع صوت الميم وانفتاح الفم مع انفجارية الكاف قد أوضح المراد وأحاط بالأمر ودل على الالتزام به.

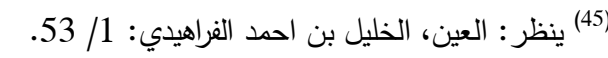

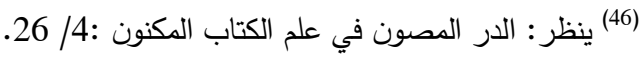

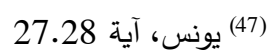

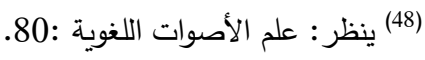

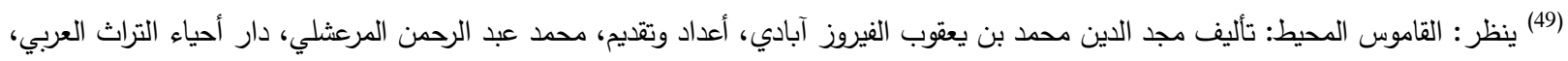

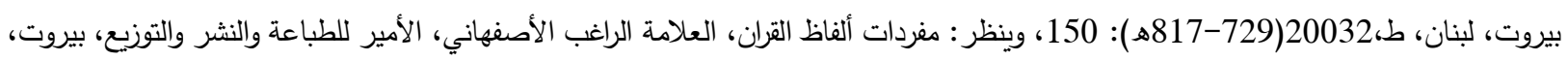


ونجد دلالة الأمر الصارم في اسم الفعل (وراء) الذي ورد في قوله عز وجل في سورة الحديد: "يَوْمَ تَرَى

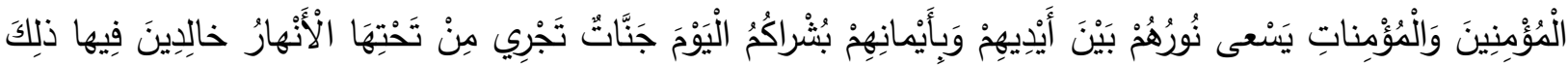

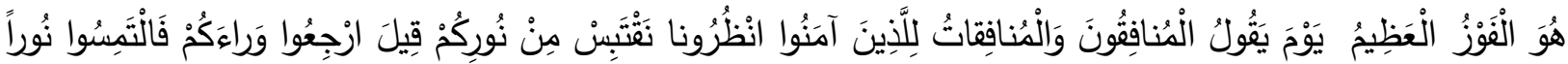

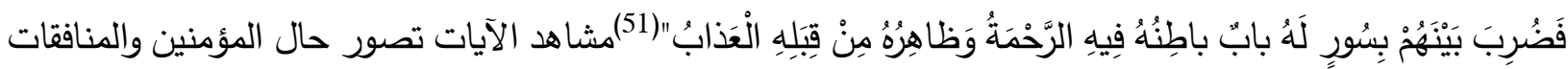
يوم القيامة، فيكون نور كل إنسان على قدر عمله، فنور المؤمنين والمؤمنات يسعى من بين أيديهم وعن إيمانهم وشمائلهم، ولا يوجد للمنافقين نور لسوء أعمالهم، فالتمسوا النور من الذين آمنوا، وهنا يأتي الأمر الصارم عليهم بأناأرجعوا، فقد ورد الأمر بالآية الكربمة، بفعل الأمر ارجعوا، واسم الفعل وراءكم، أي ارجعوا واثبتوا في مكانكم، وكأنه يأمرهم بالإقامة في مستقرهم (52) والمكوث فيه، وقيل (وراءك أوسع لك)(53)، وكأنّه سبحانه والله أعلم يأمرهم بالتراجع والمكوث في مكان أوسع لهم مناسباً لسوء أعمالهم من النفاق توبيخًا لهم وطردًا عنيفًا من رحمته حتى يضرب بينهم وبين المؤمنين بسور ، فأصوات اسم الفعل وراءكم والنبرة العالية في لفظها بعد فعل الأمر أعطت مساحة دلالية واسعة؛ لتصور حالهم وهم يستجدون النور من المؤمنين، فصوت الواو الجوفية بيّن مقدار وعمق ذلك التوبيخ لهم وصوّرت الراء بصوتها التكراري المجهور، تكرار زجرهم وطردهم من رحمته سبحانه، فهو توبيخ ممتد مع الألف بعد الراء، يأتي صوت الهمزة الحنجري الثديد؛ ليتناغم مع صوت الكاف الثديد الانفجاري الذي يتصاعد معه صوت الزجر والتوبيخ لهم، وكأنّه سبحانه وتعالى قد حدد مكانهم المتأخر بمعنى اسم الفعل(وراءكم)، ووبخهم بأصواته، فالتخلف والتراجع والاستقرار في المؤخرة، هي جزاؤكم الذي تستقرون فيه، فلا تقدم بعده أبدا.

رابعاً: دلالة اللفظ على صوته:

وهذه ما نجدها في أسماء الأفعال التي يدل لفظها على صوتها، ويمكن عدّ ذلك نوعاً من المحاكاة الصوتية وكما أسماها النحاة أسماء أصوات، فأسماء الأفعال التي حاكت أصواتها في الاستعمال القرآني كـ (أف، وي)، قد حاكت دلالات تلك الأصوات وطريقة نطقها من مخارجها، وما يشعر به المتضجر أو المتندم من شعور في تلك اللحظات، فجاءت تلك الأصوات بإيحائها وجرسها لتوحي للسامع ما كان يشعر به المتكلم، فقد حملت تلك الدلالات الصوتية إلى جانب ما تحمله أصواتها من جرس ووقع على الأذن وحركة اللسان بها؛ إيحاء بالمعنى وظلالاً وموسيقى، وهو ما يسميه علماء الصوتيات بالأنوماتوبيا(54)، فاسم الفعل (أف) ورد في ثلاثة مواضع من القران الكريم في قوله

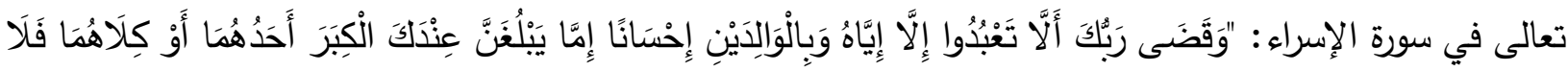

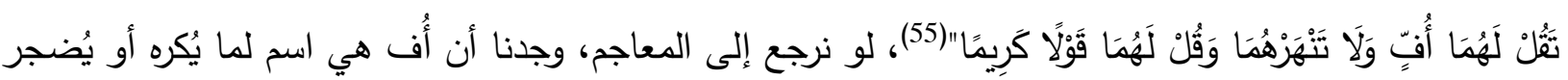

$12.13:$ (51) (52) ينظر: معجم أسماء الأفعال في اللغة العربية، إعداد أيمن عبد الرزاق الثوا، مطبوعات مجمع اللغة العربية، دمشق،2006، : 145. (53) (54) ويعنون باه موافقة صوت الكلمة لما هو مقصود منها ينظر : الفصاحة ومفهومها، تحقيق، توفيق علي الفيل، حوليات كلية الآداب جامعة الكويت،

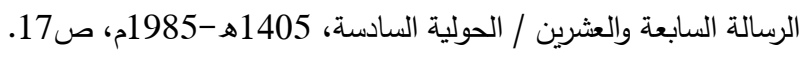
23 (55) (الاسراء 
منه، وذكروا لها الكثير من لغات(56)، ويرى أحد الدارسين أنها (أف) "ليست إلا تعبيراً لم يصل إلى حد الثبات اللغوي، وأن هذا الصوت يصدر عن الإنسان في حالة الضجر والضيق، وهي حالة انفعالية وجدانية، ولذلك تعددت صور هذا التعبير الصوتي"(57، فقد ذهب المفسرون إلى ما ذهب إليه أهل اللغة، ومنها قول أبو حيان الأندلسي في البحر المحيط

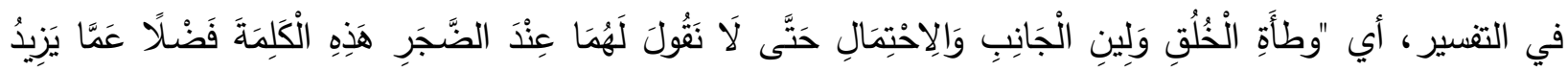

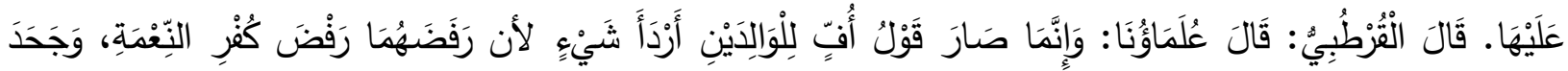

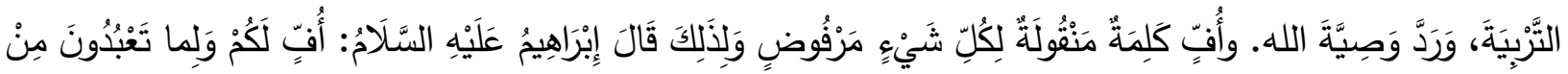

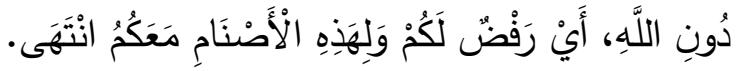

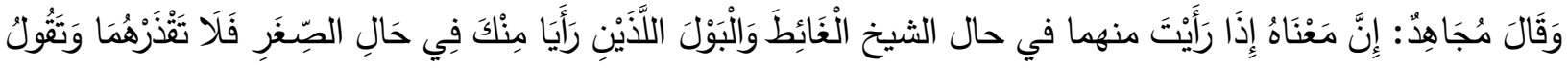

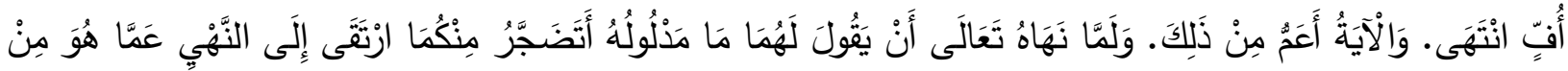

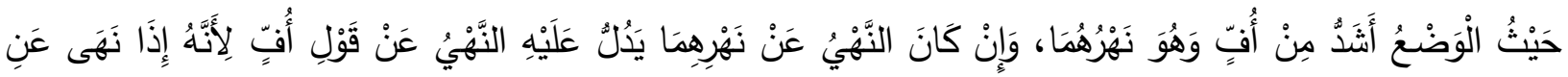

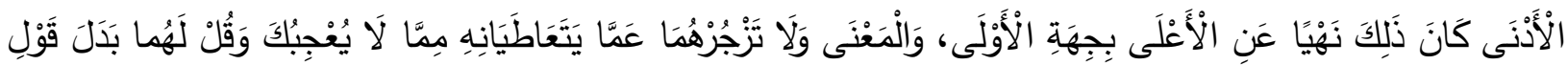

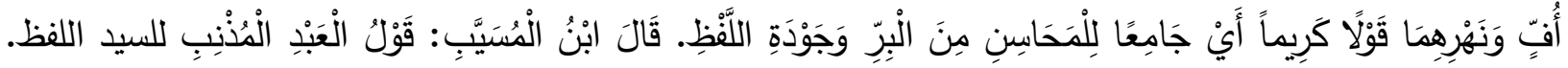

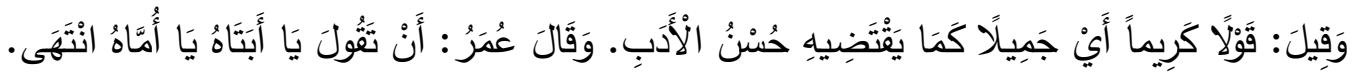

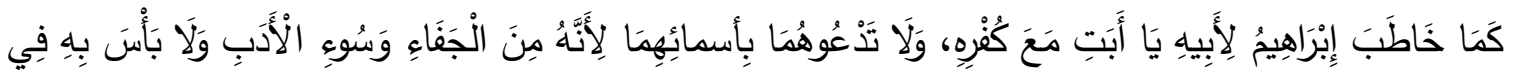

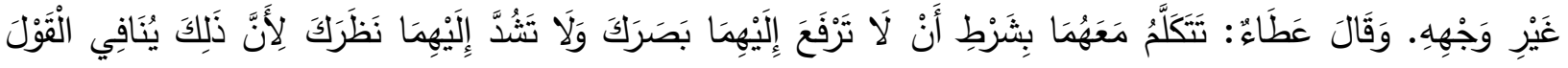

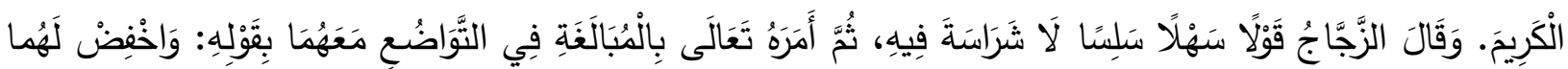

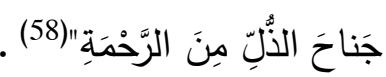

فقد عبّر عز وجل عن أدنى صوت يخرج من إنسان إذا تضجر من شيء، فالله سبحانه استعمل اسم صوت (أف)، لما تحمله أصوات هذا الاسم من دلالات، فصوت هذه الكلمة المكون من حرفين يخرج من صدر المستثقل للشيء، والذي يبدأ بصوت الهمزة الحنجري الثديد (الانفجاري)، ويليه صوت الفاء الرخو المهموس المرقق وهو صوت شفوي أسناني(59)، فقد وصفا هذا الصوت بدقة، ورسما حالة المتضجر من الثيء والمستثقل له، فبعد المخرج بين الصوتين أعطى مساحة واسعة ليجري الهواء فيها عند فتح الأوتار الصوتية بعد أقفالها إقفالا تاماً، يمر الهواء لينفجر الصوت وينساب مع صوت الفاء الرخو ليمتد الصوت باندفاع الهواء إلى الخارج من المتضجر ، وكأن صدره كان ممتلئًا بالغيظ، وقد انفجر من غيظه وأخرج صوتًا ليعلن عنه، فالعدالة الإلهية تأبى أن يصدر هذا الصوت أمام الوالدين إكراما

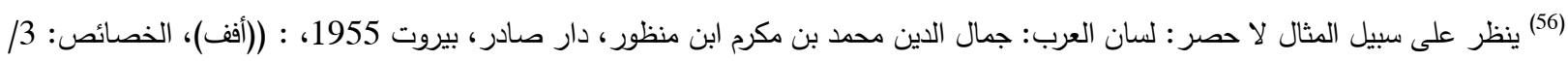
37. وتاج اللغة و صحاح العربية، حماد الجوهري الفارابي، تحقيق عبد الغفور العطار ، دار العلم للملايين، 1979 (أفف). والقاموس المحيط:(أفف).

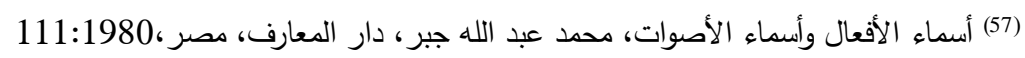

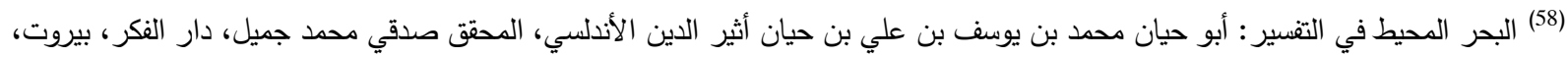


لهما، "حتى لم يرخص في أدنى كلمة تنفلت من المتضجر مع موجبات الضجر ومقتضياته، ومع أحوال لا يكاد يدخل

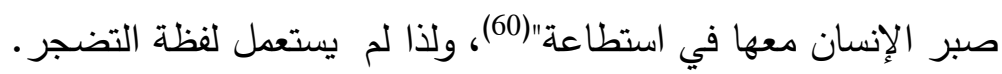

ولو رجعنا لأصل كلمة أف وجدناها كلمة تطلق على كل مستقذر من وسخ أو ما شابهه من قلامة ظفر (61)، وهنالك من المفسرين من عدّها من الأصوات، فهي صوت يدل على التضجر (62)، فأصوات اسم الفعل أف التي تصدر عن المتضجر أبلغ في نهي عن كل شيء أو قول يقال للوالدين، فنهى عن الصوت المنخفض الذي يخرج من المتضجر. فكأنه يقول سبحانه حتى الصوت المنخفض المستقبح احذر أن يصدر منك أمامهما، إكرامًا منك لهما واعترافاً بفضلهما عليك. فهذا الصوت لا يخرج إلا من ضال كافر عاق لوالديه كما ورد في سورة الأحقاف قال تعالى:

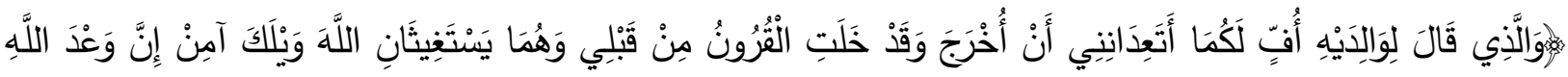

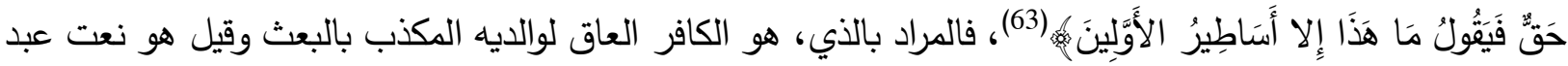
سوء عاق لوالديه فاجر لربه(64)، فصوت التضجر لا يخرج إلا من ذلك العاق الذي تجرد عن الإيمان فأفف بوالديه،

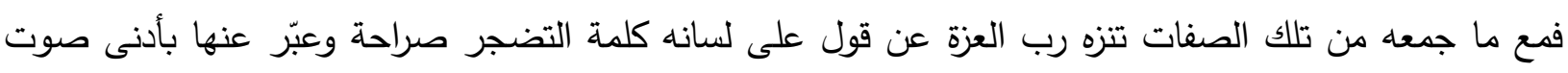
يمكن أن يخرجه العاق الكافر تنزيها لهما. كما صدر هذا الصوت عن نبي الله إبراهيم حين تضجر من قومه في قوله

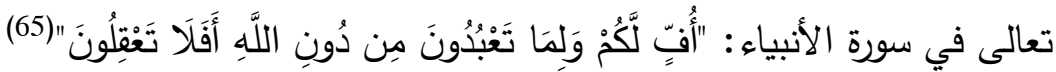

فهنا نرى تضجر نبي الله من قومه وما يعبدون من الأصنام، فقال قبحاً لكم ولآلهتكم التي تعبدونها من دون الله تعالى فقد أضجره ما رأى من ثباتهم على عبادة الأصنام بعد انقطاع عذرهم ووضوح الحق وزهوق الباطل، فتأفف

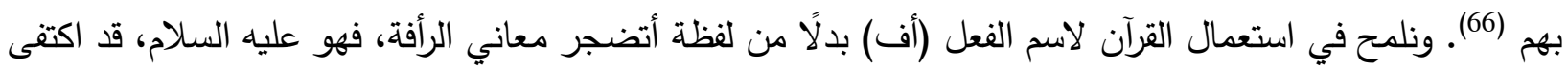
بصوت التضجر مع أن قومه قد أتعبوه بكفرهم وعدم إطاعتهم له، مع ذلك تملل وضجر منهم بأقل صوت يخرج من متضجر قد سأم من النصح والدعوة. فنرى دلالة اسم الفعل كانت ذات أثر واضح في عمق الدلالة، وبيان التضجر صوتياً، رأفة بالوالدين وإكراماً لهما، ورأفة بالدعوة والصبر في النصح والإرشاد.

أما اسم الفعل (وي) الذي يحمل معنى الندم قال عنها سييويه: "سألت الخليل عنها فزعم أن كل من ندم وأظهر ندامته قال: وي"(67)، وهو اسم فعل مضارع بمعنى أعجب، وهي كلمة يقولها المتتدم إذا أظهر ندامته(68)، ومنهم من عدّها من أسماء الأفعال والأصوات دون الفصل الواضح بقوله: "فن الأصوات قول المتندم والمتعجب وي يقول: وي

2/484: الكثاف (60) (61) ينظر : مفردات الراغب الأصفهاني، : 79 615 (62) ينظر : الكثاف:

17: (63) (63) الأحقاف (64) (65) ينظر : الكثاف: 230 67:65) 94/3: تأبظر الكثاف (66) (67) تاج العروس من جواهر القاموس، الزبيدي السيد محمد مرتضى الحسيني، طبعة الكويت: 7 / 222

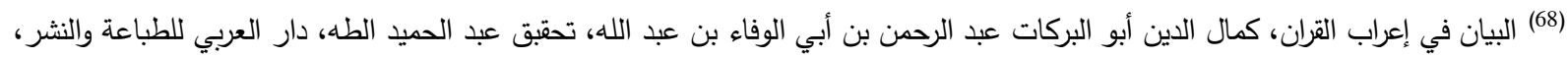


ما أغفله ويقال ويلمه... أسماء الأفعال والأصوات متواخية لأنها مزجور بها كما أن الأصوات كذلك"(69)، ونحن نتفق معه في عدّها اسماً للصوت الذي يخرجه المتعجب أو النادم والمتحسر، فهو صوت خرج من الجوف معلناً عما في نفس المتعجب من دهشة وعجب بما رأى أو سمع، لذا وجدناه قد ورد مرتين في قوله تعالى في سورة القصص: "وَأَصْبَحَ

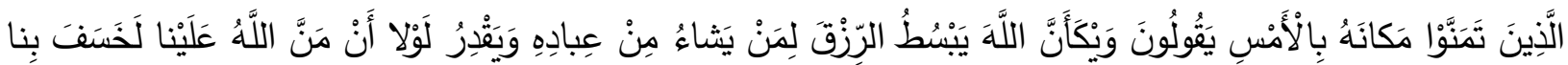

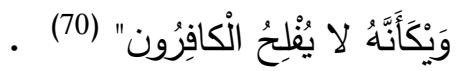

وهذا الآية في سياق الآيات التي أخبرت عن خروج قارون على قومه في زينة عظيمة، وتجمّل باهر من مراكب وملابس عليه وعلى خدمه وحشمه، فلما رآه من يريد الحياة الدنيا تمنوا لو أن لهم مثل ما أُعطي من تلك الكنوز ، وأنه ذو حظوافر فيها. فهنا أظهروا عجبهم مما ملك وكنز من الأموال والذهب لكثرته، وعجز البغال عن حمل مفاتيح كنوزه، فهو أمر عجب، فقد بسط الله له الرزق، وتمنوا لو كانوا مكانه، فكانت أصوات اسم الفعل قد رسمت تلك الدهشة والعجب الخارج من أنفسهم مع خروج الهواء عند نطقها، فنرى حال المندهش الفارغ فاه دهثة وعجباً، ألا إنهم عندما رأوا صنع الله فيه، بعد ذلك، فقد خسف به الأرض، فذهب هو وداره التي تحوي خزانه من الأموال الضخمة جزاءً له بعد ترفعه على الناس أنزله الله أسفل السافلين، وأصبح الذين تمنوا مكانه بالأمس في ندم وخوف واعتبار لما جرى عليه بعد ذلك النعيم، وعبروا عن ما يشعرون به بقولهم (وي)، فقد عبروا عن ندمهم عن قولهم السابق ب(وي) أيضاً، و"هي كلمة تنتهِهِ على الخطأ وتتدُّم" (71)، وبالصوتين الجوفين هما: (الواو، والياء) اللذين يخرجان بزفرات التحسر والتندم دون كلفة مع هواء النفس(72)، فقد دلّ خروج الهواء من الجوف على الحالة النفسية التي كانوا فيها من الندم على أمانيهح الزائلة، وتعجهح بالوقت ذاته من قدرة الله وقوته على إزالة الطواغيت بلمح البصر ، فلا فلاح للظالمين أبداً. فقد عُقب قارون بالخسف والانحطاط إلى الأرض بعد أن أراد العلو عليها، فكانت أصوات اسم الفعل (وي) أبلغ في وصف حالتهم من التوجع والاعتبار والخوف من وقوع العذاب بهم، فهم ما بين الندم والتعجب والخوف، وكلها حسرات تخرج من الجوف لتجد المتنفس لتلك المشاعر بخروج الهواء المثقل بتلك المشاعر ليستريح من الداخل مما يشعر به، فأصوات اسم الفعل ومحاكاتها للشعور قد أدت الغرض ورسمت بأصواتها ما يشعرون به في المرتين، في التعجب مرة، وفي الندم والاعتبار مرة أخرى، فقد علموا أن الله هو الذي يبسط الرزق ويقدره للعبادة، وأن بسطة الرزق لقارون ليس دليلًا على الخير فيه، وهذا ما دفعهم للإقرار بنعمه سبحانه. لذا يمكننا القول:" إن للحرف في اللغة العربية اتجاه وإيحاء ويثير في النفس جواً يقيئ لقبول المعنى ويوجه إليه ويوحي به"(73)

(69) شرح المفصل- موفق الدين بن يعيش بن علي، تحقيق أحمد السيد سعيد أحمد، إسماعيل عبد الجواد عبد الغني، المكتبة التوفيقية، القاهرة، 


\section{خامساً: دلالة الفرح العارم:}

وهذه الدلالة وجدنا في أصوات اسم الفعل (هاؤم) والذي ورد مرة واحدة في قوله تعالى في سورة الحاقة ((فَأَمَّا مَنْ أُوبِيَ

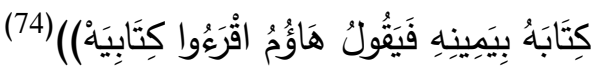
هاؤم: اسم فعل أمر منقول عن حرف التنبيه ها أو هاء، مبني على السكون بمعنى خذ، وهو اسم الفعل المنقول عن حرف غير جار، وفيه لغتان: القصر على أنها ثنائية، نحو: ها مثل: صَسْ، ومَهْ، والمد مع كاف الخطاب أو بدونها، نحو: هاء، هاكَ للمذكر وهالكِ بالكسر للمؤنث، وقد تلحقه ميم الجمع، نحو ما ورد في قوله تعالى: (هاؤم)(75)، ولو رجعنا إلى بداية السورة ونستعرضها، فهي تبدأ بلفظ الحاقة (يبرز هذا المعنى في اسم القيامة المختار في هذه السورة، والذي سميت به السورة: "الحاقة".. وهي بلفظها وجرسها ومعناها تلقي في الحس معنى الجد والصرامة والحق والاستقرار . وإيقاع اللفظ بذاته أشبه شيء برفع الثقل طويلًا، ثم استقراره استقرارًا مكينًا، رفعه في مدة الحاء بالألف، وجده في تثديد القاف بعدها، واستقراره بالانتهاء بالتاء المربوطة التي تتطق هاء ساكنة. فهذه السورة كما وصفها السيد قطب هذه سورة هائلة رهيبة، قل إن يتلقاها الحس إلا بهزة عميقة، وهي منذ افتتاحها إلى ختامها تقرع هذا الحس، وتطالعه بالهول القاصم، والجد الصارم، والمشهد تلو المشهد، كله إيقاع ملح على الحس، بالهول آنًا وبالجلال آنَا، وبالعذاب آنًا، وبالحركة القوية في كل آن! والسورة بجملتها تلقي في الحس بكل قوة وعمق إحساسًا واحدًا بمعنى واحد... إن هذا الأمر أمر الدين والعقيدة، خالص حازم جازم جداً، جد كله لا هزل فيه، ولا مجال فيه للهزل، جد في الدنيا وجد في الآخرة، وجد في ميزان الله وحسابه، جد لا يحتمل التلفت عنه هنا أو هناك كثيرًا ولا قليلًا، وأي تلفت عنه من أي أحد يستنزل غضب الله الصارم، وأخذه الحاسم(76) ، فهذا الموقف الصارم والمشاهد التي تهز النفس الإنسانية، فذلك الهول والجلال يخلعان الأمر المهول على مشهد الحساب، ويشاركان في تعميق ذلك المعنى في الحس مع سائر إيقاعات السورة وإيحاءاتها هو وما بعده من مقالة الناجين والمعذبين، فمن نجا وما يكاد يصدق بالنجاة(77)، لذا فهو من شدة فرحته بعد لم يصدق نجاته، فأصدر صوتاً يلائم ما أحس به من الفرح العارم، وكأننا نتصور فرحته مع عمق مخرج الهاء وخروج الهواء من فمه وامتداده مع رخوة صوتها، وكأننا نرى تلك الابتسامة على وجها وفرحته من الأعماق بعد تلك المشاهد والأهوال، لتمد تلك الفرحة بامتداد الألف، وتعود الثفتان لتتطبق مع صوت الميم المضمومة لتحس معه براحته النفسية بعد طول

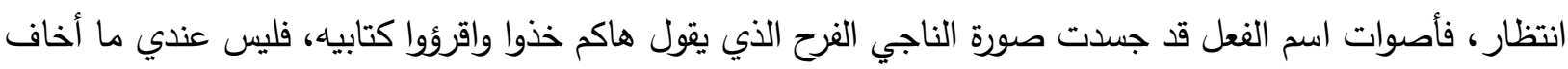
منه، فيهتف : هاؤم ليعبر عن فرحه العارم الذي ملأ المشهد. 


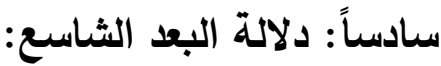

هذا ما وجدناها في اسم الفعل (هيهات) الذي ورد مرتين في موطن واحد في القرآن الكريم، في قوله تعالى في

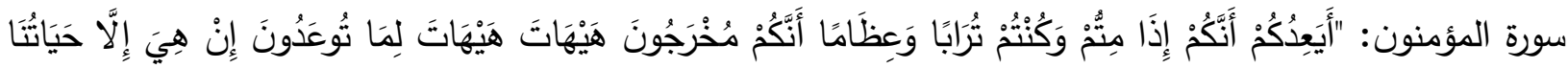

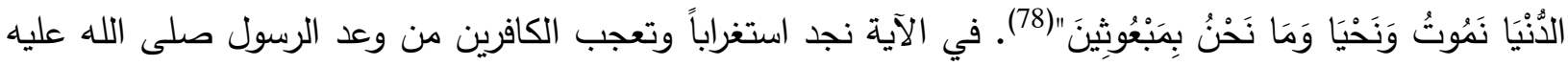

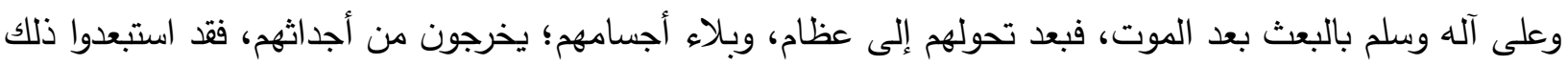

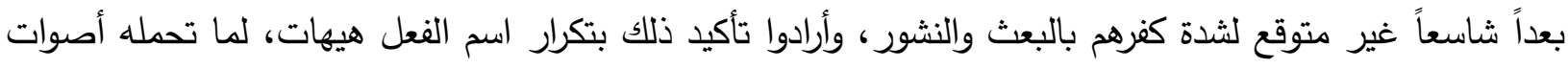
هذه الكلمة من دلالات، صورت ذلك البعد الذي كان في أذهانهم عن إمكانية بعث الموتى في الآخرة، فصوت البعاد الهاء

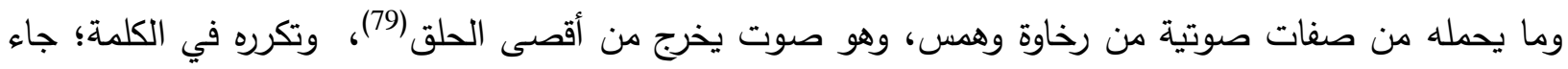

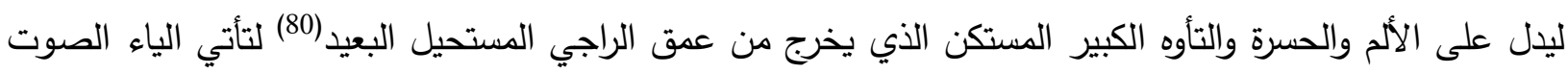

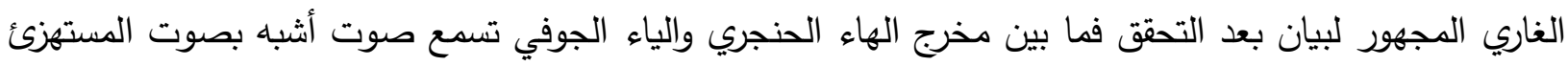

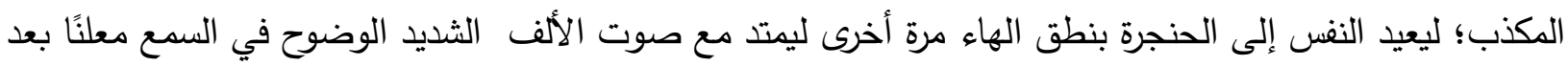

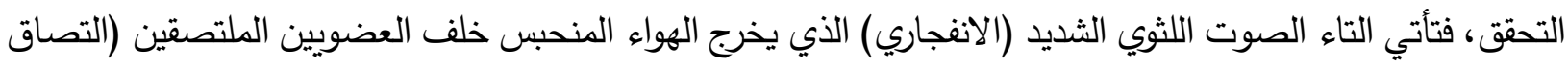

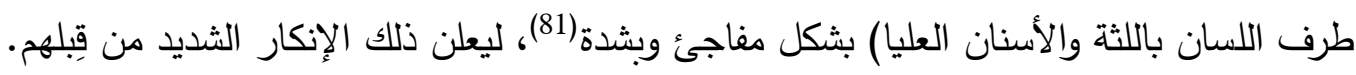

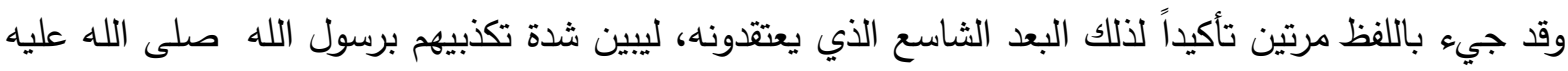

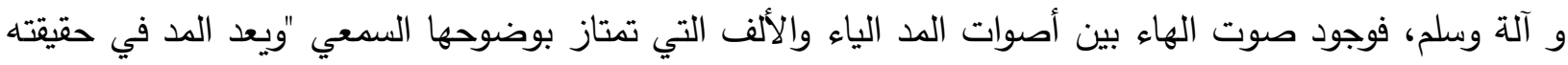

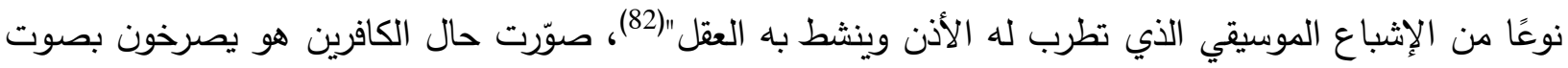

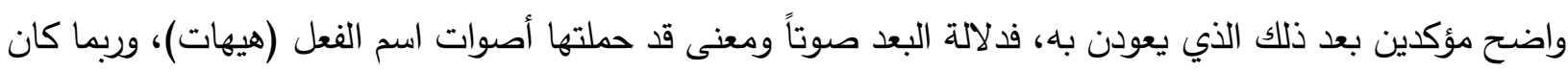

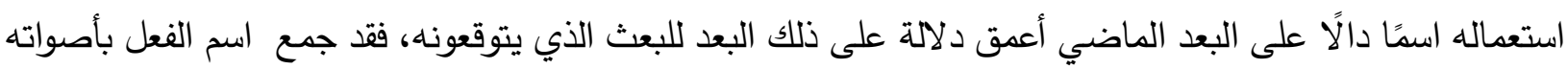

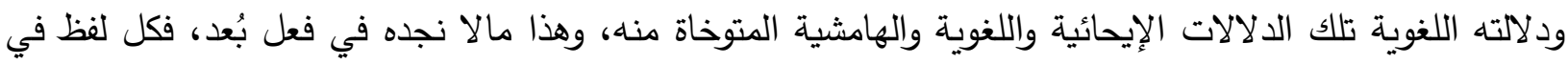
القران الكريم أختير في موضعه من الآية، لا يسد مسده غيره، وذلك من معالم أعجازه.

(80 ينظر : أسماء الأفعال في العربية (دراسة دلالية لبعض جوانبها)، إيمان بنت عبد المدني، جامعة الأميرة نورة بنت عبد الرحمن،460: 


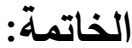

بعد ذلك التمعن في كتاب الله العزيز الذي لا يأتيه الباطل لا من بين يديه ولا من خلفه، والذي أعجز الأولين والآخرين على الإتيان بمثله، توصل البحث الى ما يأتي:

- - استعمال اسم الأفعال في مواضع من كتابه العزيز كان لأغراض دلالية ولغوية تعزز عن تأديتها الأفعال التي هي بمعناها. - - د دلالة الإسراع وشموله وإحاطته بمعانٍ ودلالات أخرى حسب حال المخاطب والخطاب الموجه إليه قد شعت بها، وأنارتها

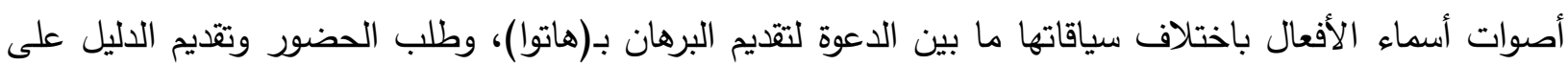

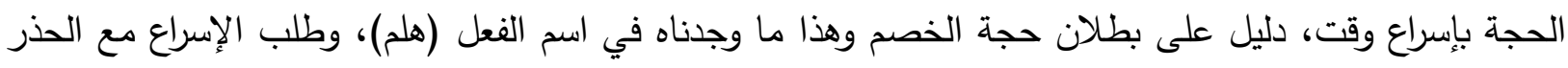

$$
\text { والترقب في (هيت). }
$$

- لـدت دلالة الكفاية المطلقة بالله سبحانه في اسم الفعل (حسب)، وكفاية جهنم معه مطلقة أيضاً، فهي العقاب الثامل والمطلق للكافرين. كانت دلالة الأمر الصارم واضحة في اسم الفعل المنقول عن الجار والمجرور (عليكم)، واسمي الفعل المنقولين عن

$$
\text { الظروف (مكانكم، وراءكم). }
$$

- دلت بعض أصوات أسماء الأفعال على الصوت نفسه، وهذا ما وجدناه في اسم الفعل (أف) الذي دل على أدنى وأكره صوتاً يمكن أن يصدر عن عاق لوالديه، أو متضجر من فعل. - وقد أوضحت أصوات الفعل (وي) حال المتعجب الخائف المعتبر من صنع الله. - وجدنا دلالة الفرح العارم في أصوات اسم الفعل (هاؤم) التي عبرت عن صوت الفرح الناجي من عذاب الله يوم القيامة.

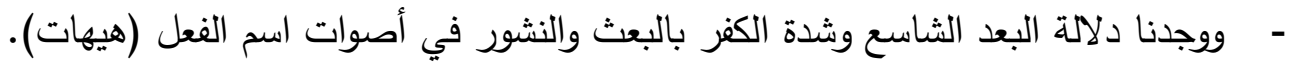

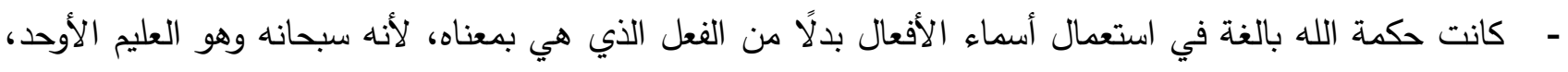
أراد دلالة الصوت، ودلالة الفعل ودلالة الاسم معا، فاختصر وكثف، وأوضح وأوجز صوتًاً ودلالة، و والله أعلم.

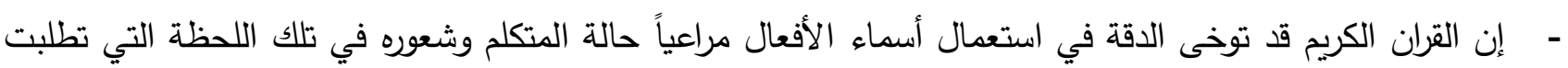

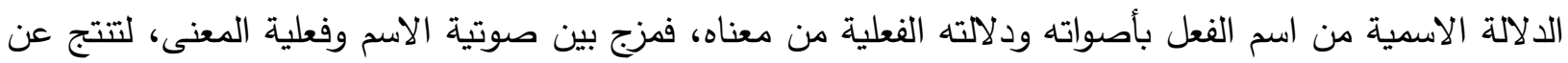
ذلك دلالات إيحائية. 


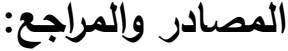

•ابن بنين الدقيقي(سليمان)، (1405)، اتفاق المعاني واختلاف المباني، تحقيق يحيى عبد الرؤوف جبر ، دار عمان، ط1.

• ابن جني: أبو الفتح عثمان (1999م)، الخصائص، تحقيق محمد علي النجار ، الهيئة المصرية العامة للكتاب، مصر . هابن جني، أبو الفتح عثمان (2004م، المحتسب في تبين وجوه القراءات والإيضاح عنها، تحقيق علي النجدي ناصف

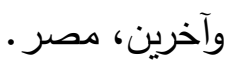
ابن كثير، أبي الفذاء اسماعيل بن عمر بن كثير القرشي الدمشي (2000) دار ابن حزم للطباعة والنشر والتوزيع،

• ابن منظور : جمال الدين محمد بن مكرم (1955م)، لسان العرب، دار صادر بيروت.

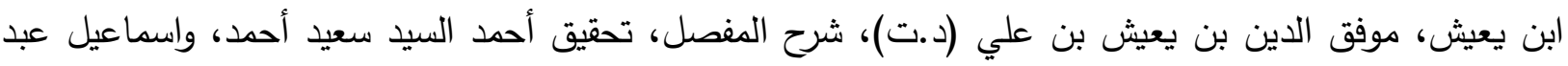
الجواد عبد الغني، الدكتبة التوفيقية، القاهرة. الاستراباذي، رضي الدين (1975)، شرح الرضي على الكافية، تحقيق وتصحيح وتعليق: يوسف حسن عمر ، منشورات جامعة قابوس بنغازي. • الأصفهاني، العلامة الراغب (1431هـ - 2010م)، مفردات ألفاظ القران، ط1، الأمير للطباعة والنشر والتوزيع، بيروت-

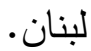
الألوسي، محمود شكري البغدادي شهاب الدين (بلا تاريخ)، روح المعاني في تفسير القران الكريم والسبع الدثاني، طبعة

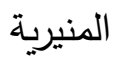
الأندلسي، أبو حيان محمد بن يوسف بن علي بن حيان أثير الدين (ت745هـ) عام (1420هـ)، البحر المحيط في التقسير، المحقق صدقي محمد جميل، دار النكر -بيروت.

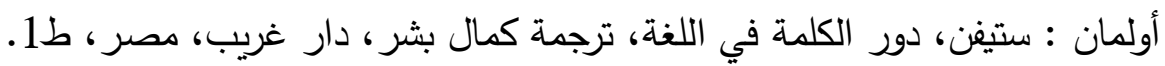

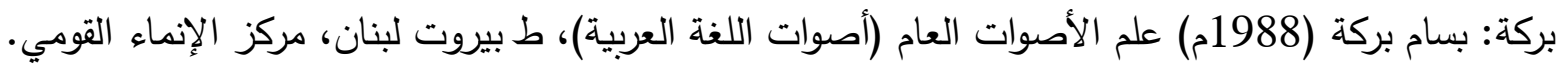

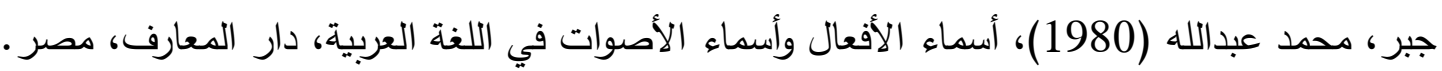

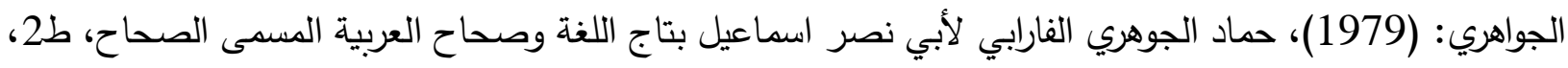
تحقيق أحدد عبد الغفور العطار، دار العلم للملايين. • الحمد، غانم قدوري (2005م)، المدخل على علم الأصوات، ط1، دار دار عمار للنشر والتوزيع.

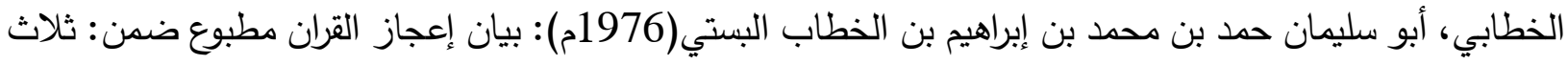

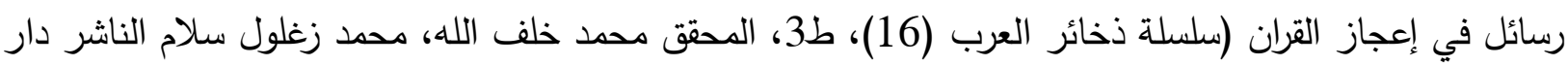

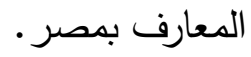

ه الرافعي مصطفى صادق (1973، إعجاز القران والبلاغة النبوية الناشر دار الكتاب العربي، ط9

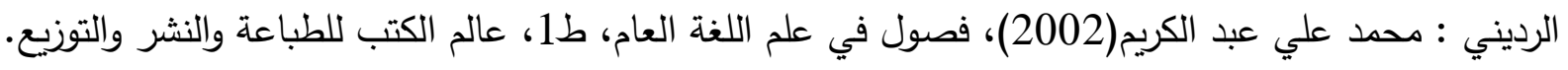
ه الزبيدي، السيد محمد مرتضى الحسيني، تاج العروس من جواهر القاموس، طبعة الكويت. 
الزجاج، أبو إسحاق إبراهيم بن السري، (1416م)، معاني القران وإعرابه، ط3 تحقيق ودراسة إبراهيم الأبياري، مطبعة إسماعيليان.

هالزخشري : أبو القاسم محمود بن عمر (1995) الكثاف عن حقائق التنزيل وعيون الأقاويل في وجوه التأويل، ط1، رتبه وضبطه، محمد عبد السلام شاهين، دار الكتب العلمية، بيروت. ه السمين الحلبي (1994م) الدر الدصون في علوم الكتاب الدكنون، ط1، تحقيق الثيخ علئ علي معوض وآخرين، دار الكتب العلمية، بيروت -لبنان. السيوطي، جلال الدين عبد الرحمن بن أبي بكر (1988م) : همع الهوامع في شرح جمع الجوامع، ط1، تحقيق أحمد الكد شمس الدين، دار الكتب العلمية، بيروت. الثوا، أيمن عبد الرزاق (1427هـ-2006م)، معجم أسماء الأفعال في اللغة العربية، ط1، مطبوعات مجمع اللغة العربية بدمشق. عكاشة، محمود (2011) التحليل اللغوي في ضوء علم الدلالة، دار النشر للجامعات، القاهرة

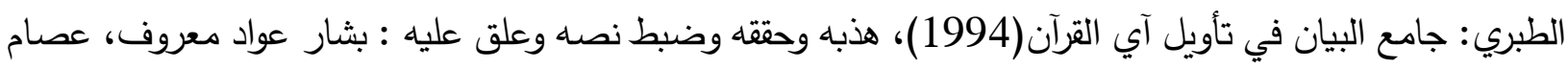

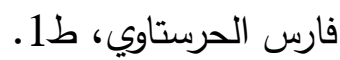
• العلايلي، أسعد احمد علي (1985م)، تهذيب المقدمة اللغوية دار السؤال للطباعة والنشر -دمشق.

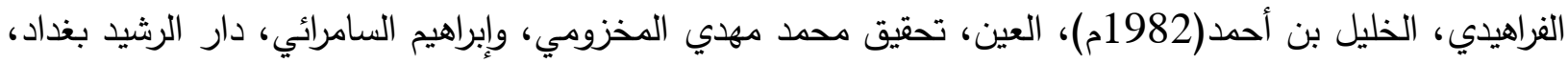
مطبعة الرسالة، الكويت.

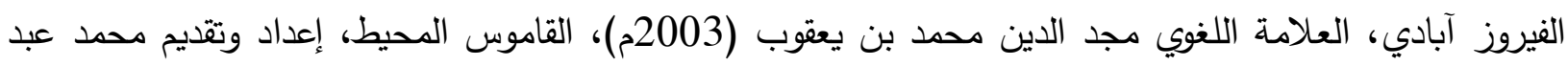

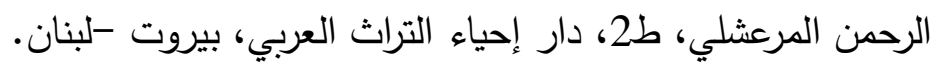

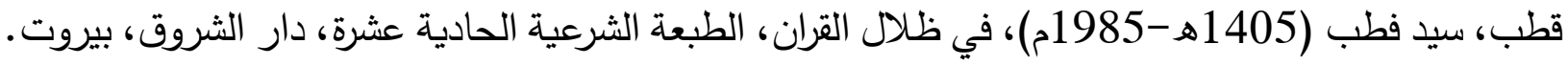

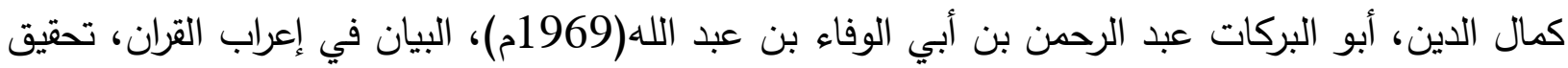
عبد الحميد طه، دار العربي للطباعة والنشر القاهرة. ه المبارك، محمد (1968م)، فقة اللغة وخصائص العربية، ط3، دار الفكر ، بيروت.

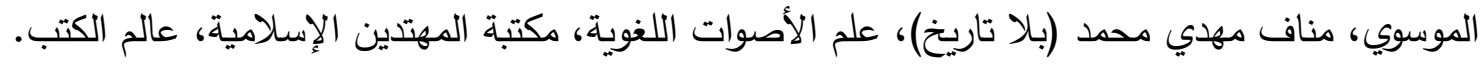
• النحاس، أبو جعفر (1985، إعراب القران الكريم، ط2، تحقيق زهير غازي الزاهد، مكتبة النهضة، عالم الكتب، بيروت.

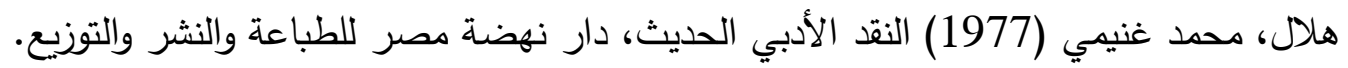

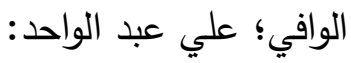
(1951) اللغة والمجتمع، ط2، دار إحياء الكتب العربية، بيروت. (1947م)، اللغة عند الإنسان والطفل، ط1ا، دار دار الفكر العربي، القاهرة. 


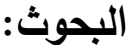

1- العبد، محمد السيد سلمان، خريف(1989م)، من صور الإعجاز الصوتي في القران الكريم، بحث منشور في المجلة العربية للعلوم الإنسانية، تصدر عن مجلس النشر العلمي، جامعة الكويت، العدد 36، مجلد التاسع. 2- العرود، زهير محمد (بحث منشو رعام 2018م)، أسماء الأفعال في الاستعمال القرآني، مجلة الأقصى للعلوم الإنسانية، • مج 22، العدد2

3- الفيل، توفيق علي (1405هـ-1985م)، الفصاحة ومفهومها وبم تتحقق، حوليات كلية الآداب جامعة الكويت، الرسالة السابعة والعشرين، الحولية السادسة. 